\title{
Hepatorenal syndrome: pathophysiology, diagnosis, and management
}

\author{
Douglas A Simonetto, ${ }^{1}$ Pere Gines, ${ }^{2}$ Patrick S Kamath ${ }^{1}$
}

\section{Check for updates}

${ }^{1}$ Division of Gastroenterology and Hepatology, Mayo Clinic College of Medicine and Science, Rochester, MN 55905, USA

${ }^{2}$ Liver Unit, Hospital Clinic, University of Barcelona IDIBAPS - CIBEReHD, Barcelona, Spain

Correspondence to:

PS Kamath

Kamath.patrick@mayo.edu

Cite this as: $B M J$ J 2020;370:m2687 http://dx.doi.org/10.1136/bmj.m2687

Series explanation: State of the Art Reviews are commissioned on the basis of their relevance to academics and specialists in the US and internationally. For this reason they are written predominantly by US authors.

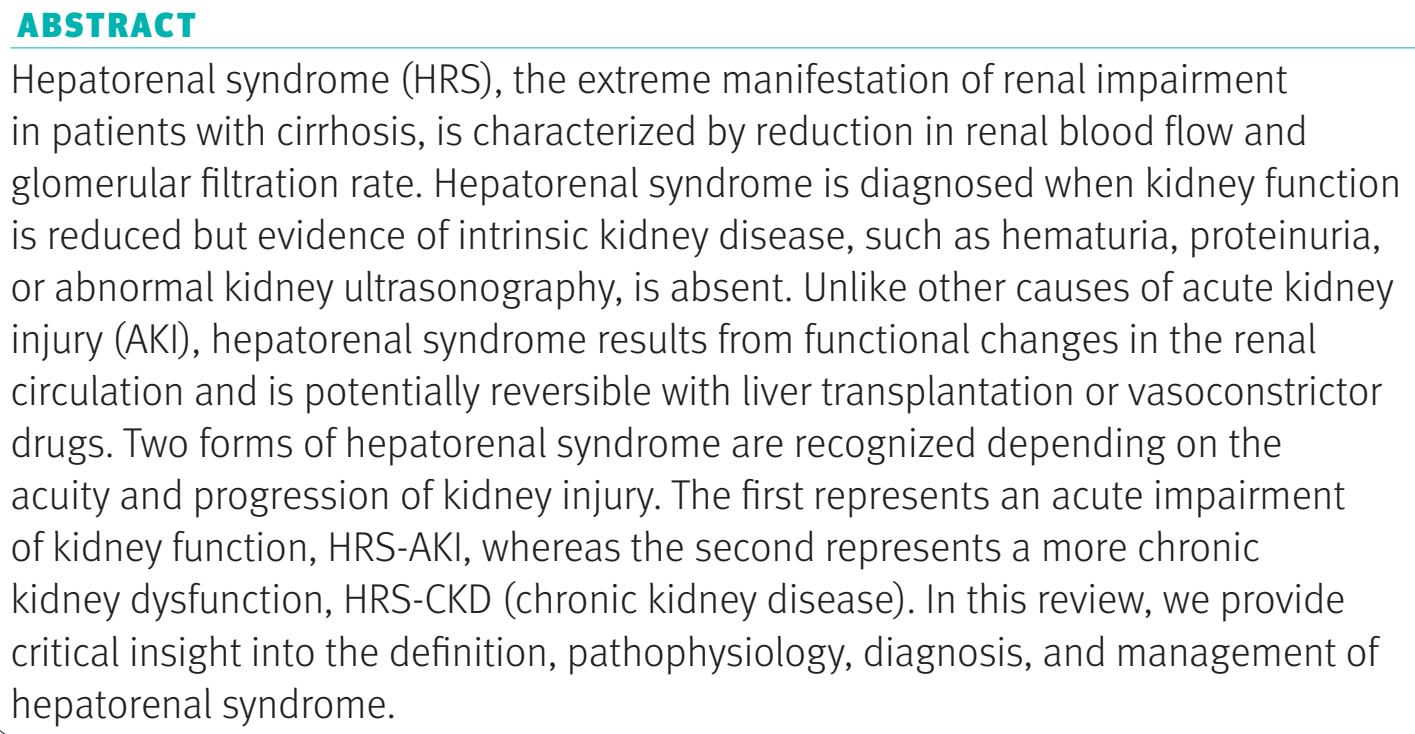

Hepatorenal syndrome (HRS), the extreme manifestation of renal impairment in patients with cirrhosis, is characterized by reduction in renal blood flow and glomerular filtration rate. Hepatorenal syndrome is diagnosed when kidney function is reduced but evidence of intrinsic kidney disease, such as hematuria, proteinuria, or abnormal kidney ultrasonography, is absent. Unlike other causes of acute kidney injury (AKI), hepatorenal syndrome results from functional changes in the renal circulation and is potentially reversible with liver transplantation or vasoconstrictor drugs. Two forms of hepatorenal syndrome are recognized depending on the acuity and progression of kidney injury. The first represents an acute impairment of kidney function, HRS-AKI, whereas the second represents a more chronic kidney dysfunction, HRS-CKD (chronic kidney disease). In this review, we provide critical insight into the definition, pathophysiology, diagnosis, and management of hepatorenal syndrome.

\section{Introduction}

Hepatorenal syndrome is a serious complication of cirrhosis that is associated with high morbidity and mortality. It is characterized by functional circulatory changes in the kidneys that overpower physiologic compensatory mechanisms and lead to reduced glomerular filtration rate. Reestablishment of adequate renal blood flow leads to improvement in renal function and is achieved with liver transplantation or vasoconstrictor drugs. The terminology, definition, and classification of hepatorenal syndrome have evolved considerably in the past 10 years owing to changes proposed for the diagnosis and staging of acute kidney injury (AKI). In this state of the art review, we focus on recent advances that have shaped the contemporary definition, diagnosis, and management of hepatorenal syndrome.

\section{Sources and selection criteria}

We searched PubMed from January 2000 to October 2019 using the keyword "hepatorenal syndrome". We prioritized randomized clinical trials (RCTs), systematic reviews, and meta-analysis, when available, excluding case reports and case series. We also reviewed published management guidelines from websites of professional societies (American Association for the Study of Liver Diseases; European Association for the Study of the Liver; Kidney Disease: Improving Global Outcomes; and others). We included only full length, peer reviewed studies published in English, with the exception of recent high profile RCTs available only in abstract form.

\section{Epidemiology and definitions}

Acute impairment of renal function, as determined by an increase in serum creatinine, is reported in $19-26 \%$ of patients admitted to hospital with cirrhosis and $32 \%$ of patients with severe alcohol associated hepatitis. ${ }^{1-4}$ Serum creatinine, however, underestimates decline in renal function in patients with cirrhosis owing to impaired hepatic production of creatine (the precursor of creatinine), reduced muscle mass, tubular secretion of creatinine, and inaccurate measurement of creatinine by calorimetric methods in the presence of elevated serum bilirubin. ${ }^{56}$ Therefore, alternative biomarkers with greater accuracy in patients with cirrhosis are urgently needed. Incorporating cystatin C, a cysteine proteinase inhibitor, into conventional creatinine based glomerular filtration rate (GFR) equations results in better diagnostic performance compared with conventional equations alone. ${ }^{7}$

Despite the limitations, serum creatinine remains the most widely available and inexpensive assay for estimation of GFR. In a non-steady state such as acute renal failure, serial changes in creatinine and urine output better reflect renal function. Consequently, the definition of acute renal failure has evolved over the past two decades. The RIFLE (risk, injury, failure, loss, and end stage kidney disease) classification, generated at the Consensus Conference of the Acute Dialysis Quality Initiative Group in 2002, consisted of percentage changes in serum creatinine or GFR, a decrease in urine output, or both. ${ }^{8}$ This classification was later refined by a second multidisciplinary collaborative forum held in 2005, the Acute Kidney 
Injury Network (AKIN). ${ }^{9}$ The AKIN first proposed the term acute kidney injury (AKI) to include the entire spectrum of acute renal failure and also added an absolute increase in serum creatinine of $0.3 \mathrm{mg} / \mathrm{dL}$ within 48 hours of baseline as part of the definition of AKI. This change was based on accumulating evidence that even small acute increments in serum creatinine were associated with significant short term morbidity and mortality. ${ }^{10}{ }^{11}$ In 2012 the Kidney Disease Improving Global Outcome (KDIGO) organization published clinical practice guidelines further refining the diagnosis of AKI on the basis of the RIFLE and AKIN criteria. The KDIGO defined $\mathrm{AKI}$ as an increase in serum creatinine by at least $0.3 \mathrm{mg} / \mathrm{dL}(26.5 \mu \mathrm{mol} / \mathrm{L})$ within 48 hours, an increase in serum creatinine to at least 1.5 times baseline within the previous seven days, or urine volume below $0.5 \mathrm{~mL} / \mathrm{kg} / \mathrm{h}$ for six hours. ${ }^{12}$

The definition of hepatorenal syndrome has likewise evolved in the past two decades to align with the changes proposed by the RIFLE, AKIN, and KDIGO guidelines. In 1990 the International Club of Ascites (ICA) defined acute renal failure in cirrhosis as an increase in serum creatinine of at least 50\% from baseline to a final concentration of at least $1.5 \mathrm{mg} / \mathrm{dL}$. Hepatorenal syndrome was further subclassified into two clinical types: type 1, defined as rapid reduction of renal function by doubling of initial serum creatinine to a concentration of at least $2.5 \mathrm{mg} / \mathrm{dL}$ or a $50 \%$ reduction in less than two weeks in the initial 24 hour creatinine clearance to below $20 \mathrm{~mL} / \mathrm{min}$; and type 2 , in which renal failure progression did not meet the criteria for type . $^{13}$

Several recent studies showed that the diagnosis of AKI in patients with cirrhosis, based on an absolute increase in serum creatinine by at least $0.3 \mathrm{mg} / \mathrm{dL}$ or $50 \%$ from baseline, leads to earlier identification of patients at increased risk of longer hospital stay, multi-organ failure, admission to intensive care, and in-hospital mortality as well as 90 day mortality. ${ }^{114-18}$ This led the ICA to issue a revised set of consensus recommendations in 2015, incorporating a new definition and classification of AKI with modifications (box 1). ${ }^{19}$ A serum creatinine concentration obtained in the previous three months can be used as baseline when a concentration in the previous seven days is not available. The ICA also eliminated urine output in the revised definition of AKI, owing to expected lower urine output at baseline in patients with cirrhosis due to avid sodium and water retention. However, a recent study showed that patients in the intensive care unit with reduction in urine output to below $0.5 \mathrm{~mL} / \mathrm{kg}$ for at least six hours had a higher mortality than did those who met only the creatinine criteria for AKI. ${ }^{20}$ Therefore, accurate urine output (for example, when obtained through a urinary catheter) may be used for diagnosis and staging of AKI. ${ }^{21}$

The ICA also updated the definition of hepatorenal syndrome (HRS) type 1, now termed HRS-AKI. The two week interval required for doubling in serum creatinine in the previous definition could lead
Box 1: Stages of acute kidney injury according to the International Club of Ascites ${ }^{19}$

\section{Stage 1}

Increase in serum creatinine $\geq 0.3 \mathrm{mg} / \mathrm{dL}(26.5 \mu \mathrm{mol} / \mathrm{L})$ or increase in serum creatinine $\geq 1.5$-fold to twofold from baseline

- Stage $1 a$

- Creatinine $<1.5 \mathrm{mg} / \mathrm{dL}$

- Stage $1 b$

- Creatinine $\geq 1.5 \mathrm{mg} / \mathrm{dL}$

Stage 2

Increase in serum creatinine at least twofold to threefold from baseline

Stage 3

Increase in serum creatinine at least threefold from baseline or serum creatinine $\geq 4.0 \mathrm{mg} / \mathrm{dL}$

$(353.6 \mu \mathrm{mol} / \mathrm{L})$ with an acute increase $\geq 0.3 \mathrm{mg} / \mathrm{dL}$

$(26.5 \mu \mathrm{mol} / \mathrm{L})$ or initiation of renal replacement therapy

to a delay in starting treatment for hepatorenal syndrome; several studies have shown that the higher the creatinine at the start of treatment, the lower the probability of reversal of hepatorenal syndrome. ${ }^{22} 23$ Therefore, no minimum creatinine value is needed for the diagnosis of HRS-AKI according to the updated definition. That is, HRS-AKI can be diagnosed even when the serum creatinine is below $2.5 \mathrm{mg} / \mathrm{dL}$.

Functional kidney injury in patients with cirrhosis that does not meet the criteria for HRS-AKI is termed HRS-NAKI (that is, non-AKI) and is defined by estimated glomerular filtration rate (eGFR) rather than serum creatinine. ${ }^{24}$ NAKI is divided into HRSacute kidney disease (HRS-AKD) if the eGFR is less than $60 \mathrm{~mL} / \mathrm{min} / 1.73 \mathrm{~m}^{2}$ for less than three months and HRS-chronic kidney disease (HRS-CKD) if it is less than this for more than three months (fig 1).

\section{Pathophysiology}

Our understanding of the pathophysiology of hepatorenal syndrome is mostly based on observational studies in humans because of the lack of a reproducible experimental model of hepatorenal syndrome. The challenge faced with animal models is the inability to induce severe liver injury without direct kidney toxicity as with carbon tetrachloride and thioacetamide. Nevertheless, clinical and histopathologic observations point to an uncompensated hyperdynamic circulation as the hallmark of AKI-HRS. Additional contributors to development of AKI-HRS include systemic inflammation, cirrhotic cardiomyopathy, and adrenal insufficiency.

\section{Circulatory dysfunction}

The hemodynamic changes in patients with cirrhosis are linked to sodium retention, development of ascites, and subsequent renal dysfunction. ${ }^{25}$ Cirrhosis results in elevated intrahepatic vascular resistance but splanchnic vasodilatation due to 


\begin{tabular}{|c|c|}
\hline HRS type 1 & HRS-AKI \\
\hline $\begin{array}{l}\text { Doubling of serum creatinine to a concentration } \geq 2.5 \\
\mathrm{mg} / \mathrm{dL} \text { within } 2 \text { weeks } \\
\text { No response to diuretic withdrawal and } 2 \text { day fluid } \\
\text { challenge with } 1 \mathrm{~g} / \mathrm{kg} / \text { day of albumin } 20-25 \% \\
\text { Cirrhosis with ascites } \\
\text { Absence of shock } \\
\text { No current or recent use of nephrotoxic drugs (NSAIDs, } \\
\text { contrast dye, etc) } \\
\text { No signs of structural kidney injury } \\
\text { - Absence of proteinuria ( }>500 \mathrm{mg} / \text { day) } \\
\text { - Absence of hematuria ( }>50 \mathrm{RBCs} \text { per high power } \\
\text { field) } \\
\text { - Normal findings on renal ultrasonography }\end{array}$ & $\begin{array}{l}\text { Increase in serum creatinine of } \geq 0.3 \mathrm{mg} / \mathrm{dL} \text { within } 48 \\
\text { hours } \\
\text { OR } \\
\text { Increase in serum creatinine } \geq 1.5 \text { times from baseline } \\
\text { (creatinine value within previous } 3 \text { months, when } \\
\text { available, may be used as baseline, and value closest to } \\
\text { presentation should be used) } \\
\text { a Ne response to diuretic withdrawal and } 2 \text { day fluid } \\
\text { challenge with } 1 \mathrm{~g} / \mathrm{kg} / \text { day of albumin } 20-25 \% \\
\text { - Cirrhosis with ascites } \\
\text { Absence of shock } \\
\text { no current or recent use of nephrotoxic drugs (NSAIDs, } \\
\text { contrast dye, etc) } \\
\text { - No signs of structural kidney injury } \\
\text { - Absence of proteinuria ( }>500 \mathrm{mg} / \text { day) } \\
\text { - Absence of hematuria ( }>50 \text { RBCs per high power } \\
\text { field) } \\
\text { - Normal findings on renal ultrasound }\end{array}$ \\
\hline HRS type 2 & HRS-NAKI \\
\hline $\begin{array}{l}\text { Gradual increase in serum creatinine, not meeting } \\
\text { criteria above }\end{array}$ & $\begin{array}{l}\text { HRS-AKD } \\
\text { Estimated glomerular filtration rate }<60 \mathrm{~mL} / \mathrm{min} / 1.73 \mathrm{~m}^{2} \\
\text { for }<3 \text { months in absence of other potential causes of } \\
\text { kidney disease } \\
\text { - Percentage increase in serum creatinine }<50 \% \text { using last } \\
\text { available value of outpatient serum creatinine within } 3 \\
\text { months as baseline value } \\
\text { HRS-CKD } \\
\text { Estimated glomerular filtration rate }<60 \mathrm{~mL} / \mathrm{min} / 1.73 \mathrm{~m}^{2} \\
\text { for } \geq 3 \text { months in absence of other potential causes of } \\
\text { kidney disease }\end{array}$ \\
\hline
\end{tabular}

Fig 1 | Previous and current definitions of hepatorenal syndrome (HRS). AKD=acute kidney disease; AKI=acute kidney injury; CKD=chronic kidney disease; NAKI=non-acute kidney injury; NSAID=non-steroidal anti-inflammatory drug; RBC=red blood cell

increased production of vasodilators, including nitric oxide, carbon monoxide, prostacyclins, and endocannabinoids, in the splanchnic circulation. Systemic vasodilation results in reduction of effective arterial blood volume (EABV) and systemic arterial pressure. With progression of liver disease, reduction in cardiac output often precedes the development of hepatorenal syndrome, while the peripheral vascular resistance remains unchanged. ${ }^{26}$ These findings suggest a role for cirrhotic cardiomyopathy in the pathogenesis of hepatorenal syndrome.

Systemic vasoconstrictor pathways, such as the renin-angiotensin-aldosterone system, sympathetic nervous system, and arginine vasopressin, are activated as a means of increasing the EABV. These mechanisms result in sodium retention, impaired solute-free water excretion and renal vasoconstriction, and, consequently, reduced renal blood flow (fig 2).

In earlier stages, the kidneys are able to maintain a normal glomerular filtration rate owing to the vasodilatory effect of renal prostaglandins (prostaglandin I2 and prostaglandin E2) on afferent renal arterioles. Thus, glomerular pressure can initially be maintained despite reduced renal blood flow. This balance is disrupted with progression of liver disease and by drugs such as non-steroidal anti-inflammatory agents that inhibit prostaglandin synthesis and reduce filtration fraction, leading to AKI.

Elevated ammonia in cirrhosis disrupts metabolism of arginine, an essential amino acid for the synthesis of nitric oxide. ${ }^{27}$ Decreased availability of nitric oxide in the renal microcirculation contributes to impaired renal blood flow and consequent functional and ischemic kidney injury.

\section{Systemic inflammation}

Systemic inflammatory response syndrome has been observed in almost half of patients with AKI-HRS, independent of the presence of infection. ${ }^{28}$ Moreover, plasma concentrations of pro-inflammatory 


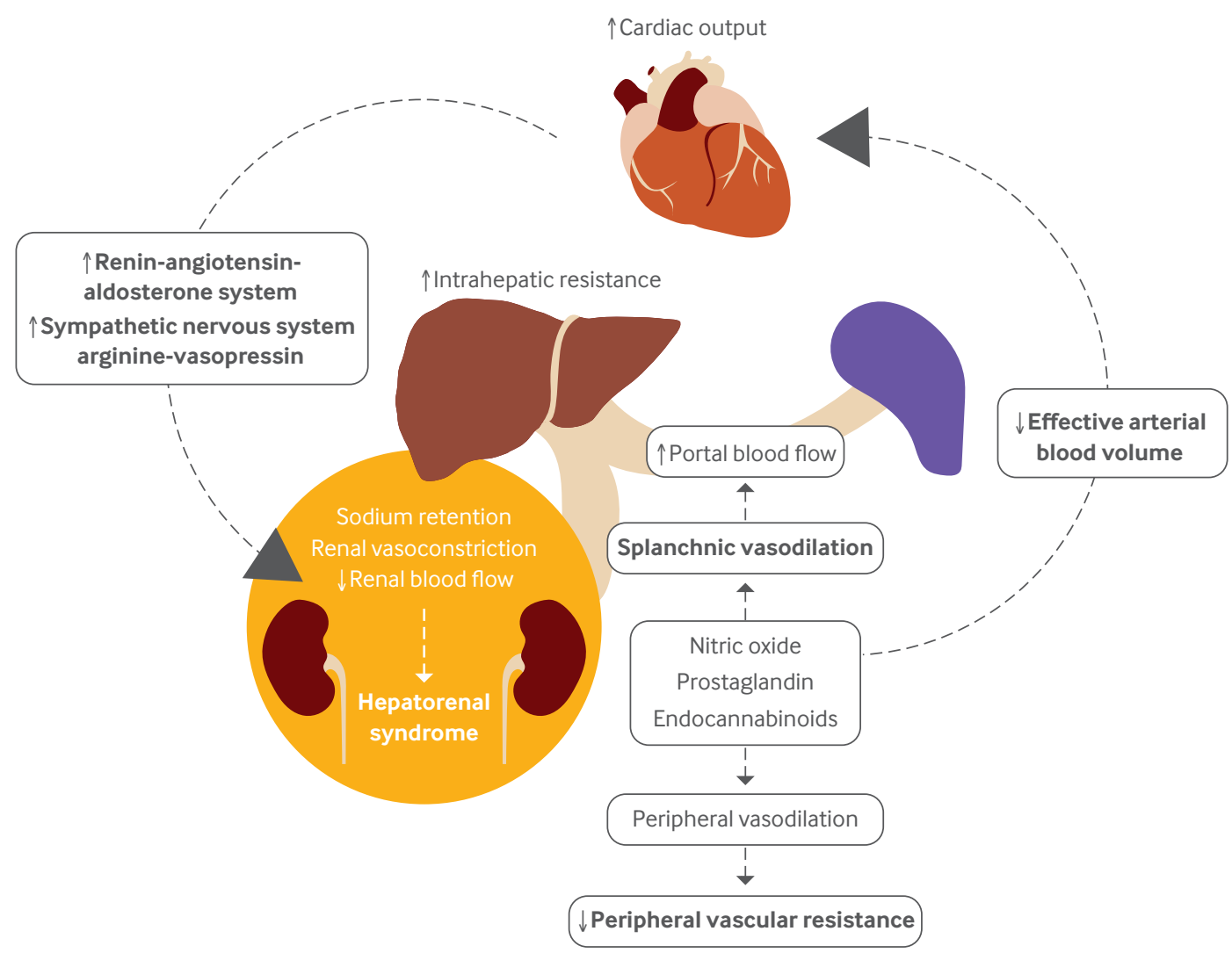

Fig 2 | Pathophysiology of hepatorenal syndrome

cytokines (interleukin-6, tumor necrosis factor- $\alpha$ (TNF- $\alpha$ ), vascular cell adhesion protein-1, and interleukin-8) and urinary concentrations of monocyte chemoattractant protein-1 are increased in patients with AKI-HRS compared with those with decompensated cirrhosis without AKI and patients with AKI secondary to pre-renal azotemia. ${ }^{29}$

Inflammation in cirrhosis is driven by two groups of molecules: pathogen associated molecular patterns (PAMPs) and damage associated molecular patterns (DAMPs). PAMPs represent bacterial products, such as lipopolysaccharide, flagellin, and nigericin, which result from translocation of gut bacteria or bacterial infections, whereas DAMPs represent intracellular components released from injured hepatocytes, including high mobility group protein B1, heat shock protein, adenosine triphosphate, double stranded genomic DNA, and others. In the absence of overt bacterial infection, both PAMPs and DAMPs may drive inflammation and release of pro-inflammatory cytokines through activation of pattern recognition receptors such as toll-like receptors (TLRs). The systemic pro-inflammatory response, in turn, may lead to increased arterial production of vasodilators (such as nitric oxide) and, consequently, further reduction in systemic vascular resistance and EABV.

In addition to a systemic effect, DAMPs and PAMPs may have a direct role in the kidneys. Patients with cirrhosis and renal dysfunction show increased expression of TLR4 receptors and caspase-3 in tubular renal cells, both important components of the innate immune system. ${ }^{30}$ Gut decontamination has been shown to reduce renal expression of TLR4 and prevent renal dysfunction and tubular damage in animal models of cirrhosis, suggesting that increased TLR4 expression in the kidneys may result from exposure to PAMPs. ${ }^{31}$ Expression of TLR4 and other pattern recognition receptors may also increase as a result of renal ischemia secondary to reduced renal blood flow in hepatorenal syndrome. ${ }^{32} 33$ In experimental models of ischemic AKI, innate immunity has been shown to be responsible for the renal damage. ${ }^{34}$ Nevertheless, further studies are needed to elucidate the exact mechanisms by which systemic inflammation leads to hepatorenal syndrome.

\section{Hepato-adrenal syndrome}

Relative adrenal insufficiency (RAI) is present in $24-47 \%$ of patients with decompensated cirrhosis and ascites and may play a role in the development of hepatorenal syndrome. ${ }^{35-37}$ Compared with patients with normal adrenal function, those with RAI have lower arterial pressure and higher serum concentrations of renin and noradrenaline and are at increased risk of AKI-HRS, sepsis, and short term mortality. ${ }^{37-40}$

The mechanisms leading to the development of hepato-adrenal syndrome remain elusive but may relate to exhaustion of substrates for synthesis of cortisol and impairment of the hypothalamuspituitary axis by circulating PAMPs and pro- 
inflammatory cytokines. ${ }^{41} 42$ Treatment with hydrocortisone may improve outcomes in patients with RAI and septic shock, including shock resolution and short term survival. ${ }^{43}$ However, the effect of glucocorticoid replacement therapy for hepatoadrenal syndrome in the absence of shock and its role in prevention and treatment of hepatorenal syndrome remain to be determined.

\section{Cholemic (or bile cast) nephropathy}

Cholemic nephropathy has long been reported in patients with cirrhosis and high serum bilirubin concentrations and is thought to be caused by formation of obstructing intratubular bile acid casts and direct bile acid toxicity to tubular cells. Histopathologic studies have shown the presence of intratubular bile acid casts in $18-75 \%$ of patients with AKI-HRS. ${ }^{445}$ Urinary bilirubin and urobilinogen are elevated in most patients and may be clues to the diagnosis. ${ }^{44}$ Cholemic nephropathy may be present in most patients with jaundice and AKI-HRS and possibly affects outcomes and treatment response, but the prevalence is likely underestimated. Serum bilirubin concentrations above $10 \mathrm{mg} / \mathrm{dL}$ have been associated with a lower rate of response to vasoconstrictors in patients with AKI-HRS compared with patients with serum bilirubin below $10 \mathrm{mg} / \mathrm{dL}$ (13\% v 67\%; $\mathrm{P}=0.001) .{ }^{4647}$ Treatments targeting bile acids in patients with jaundice and AKI-HRS may therefore be beneficial. A recent study in an experimental model of biliary cirrhosis showed that administration of norursodeoxycholic acid ameliorates renal function and histologic findings and may represent a therapeutic option for cholemic nephropathy. ${ }^{48}$ Nevertheless, the pathophysiologic contribution of cholemic nephropathy to AKI-HRS has not been convincingly demonstrated and needs further investigation.

\section{Intra-abdominal hypertension}

Elevated intra-abdominal pressure $(>12 \mathrm{~mm} \mathrm{Hg})$ is an underappreciated cause of AKI and may play a role in the development of hepatorenal syndrome in patients with refractory ascites. A small study assessing the short term effects of paracentesis in patients with hepatorenal syndrome showed a significant improvement in creatinine clearance after reduction of intra-abdominal pressure. ${ }^{49}$ However, careful monitoring of systemic hemodynamic parameters with guided plasma expansion to prevent development of post-paracentesis circulatory dysfunction is paramount. The use of bedside echocardiography for estimation of inferior vena cava diameter and collapsibility may help to determine whether intra-abdominal hypertension might be contributing to renal dysfunction and, thus, help to identify which patients may benefit from large volume paracenteses. ${ }^{50}$

\section{Hepatorenal reflex hypothesis}

A link between the kidneys and the liver has long been proposed, suggesting the presence of osmoreceptors, chemoreceptors, and baroreceptors in the liver that directly affect kidney function through complex neural circuits. ${ }^{51}$ This hypothesis has been supported by several experimental studies through manipulation of portal blood osmolality and/or chemical composition, as well as changes in portal pressure. One animal study showed that activation of intrahepatic adenosine receptors in response to reduced portal venous blood flow results in renal sodium and water retention, similar to that observed in hepatorenal syndrome. ${ }^{52}$ Although these findings may have important clinical implications, further studies translating these results to humans are needed.

\section{Differential diagnosis and biomarkers}

One important diagnostic criterion for AKI-HRS is exclusion of structural kidney injury, which relies on urine microscopy and urine sodium excretion. Pre-renal azotemia represents the leading cause of AKI in patients with cirrhosis (46-66\% of all cases), owing to frequent use of diuretics, large volume paracenteses without albumin, gastrointestinal bleeding, and gastrointestinal fluid losses secondary to lactulose induced diarrhea. ${ }^{53}$ The reported prevalence of AKI-HRS and acute tubular necrosis (ATN) varies widely, likely reflecting the challenge in differentiating the two conditions. The diagnosis of AKI-HRS requires the absence of shock, proteinuria (>500 mg/day), and microhematuria (>50 red blood cells per high power field), along with normal renal ultrasonography. However, patients who fulfill these criteria may still have tubular damage, so ATN cannot be confidently excluded.

Some experts have used urinary sodium (>40 mEq/L), fractional excretion of sodium (FeNa $>2 \%$ ), and low urine osmolality (<400 mOsm/L) as suggestive of ATN; however, urinary sodium can be elevated secondary to diuretics, frequently used in this group of patients with large volume ascites. ${ }^{55}$ Conversely, low FeNa has also been observed in patients with biopsy proven $\mathrm{ATN}^{56}$ so urinary sodium and FeNa are no longer part of the diagnostic criteria of AKI-HRS. Studies in patients without liver disease have found that fractional excretion of urea is superior to FeNa in differentiating AKI-HRS from ATN in patients taking diuretics. ${ }^{57}$ Reabsorption of urea, as opposed to sodium, occurs primarily in the proximal renal tubules and, therefore, is not affected by diuretics such as furosemide and spironolactone, which act in the loop of Henle and distal tubules, respectively. ${ }^{57}$ In a recent study assessing the role of fractional excretion of urea in derivation and validation cohorts of patients with cirrhosis and AKI taking diuretics, the area under the receiver operating characteristic curve to differentiate ATN from other causes (cut-off 33.4, sensitivity 85, and specificity 100) was $0.96 .^{58}$

Novel urine biomarkers of tubular injury have long been sought to differentiate AKI-HRS and ATN in patients with cirrhosis. Candidate biomarkers include tubular proteins released during cell damage 
(N-acetyl- $\beta$-D-glucosaminidase,

$\alpha$-glutathione S-transferase), tubular proteins up regulated by injury (kidney injury molecule-1, neutrophil gelatinase associated lipocalin (NGAL), liver-type fatty acid binding protein), plasma proteins with diminished tubular reabsorption ( $\alpha-1$-microglobulin, $\beta$-2-microglobulin, retinol binding protein), and markers of inflammation (interleukin-18). ${ }^{59} 60$ Among these, NGAL has been the most widely studied biomarker in patients with cirrhosis and has shown the greatest diagnostic accuracy in differentiating ATN from AKI-HRS. ${ }^{61-66}$ Urinary NGAL seems to be superior to plasma concentrations and performs better when measured after the two day volume challenge recommended in the management of AKI. The urinary NGAL cut-off value of $220 \mu \mathrm{g} / \mathrm{g}$ of creatinine obtained after the fluid challenge has the highest diagnostic accuracy for ATN (odds ratio 42.9, $95 \%$ confidence interval 13.9 to 132.3$).^{64}$ Moreover, urinary NGAL is an independent predictor of short term mortality. ${ }^{626466}$ One of the limitations of biomarker studies in this population is the lack of a gold standard short of kidney biopsy. Because of the inherent risks, kidney biopsies are not routinely obtained in clinical practice, and human studies rely on expert adjudication for differentiating ATN from AKI-HRS. Nevertheless, the results are encouraging and justify further study.

\section{Risk factors and prevention}

Hyponatremia, high plasma renin activity, and liver size, ${ }^{67}$ as well as severity of ascites, ${ }^{68}$ are predictors of AKI- HRS. Acute hemodynamic changes associated with infections and large volume paracentesis without albumin administration represent the most common precipitants of AKI-HRS. The prevalence of unprecipitated AKI is low $(1.8 \%){ }^{68}$ AKI-HRS develops in as many as $30 \%$ of patients with spontaneous bacterial peritonitis (SBP), ${ }^{69}$ as well as other infections, ${ }^{70} 71$ and is associated with worse outcomes. ${ }^{47} 72$ Infection associated AKI-HRS may be prevented by administration of intravenous albumin in addition to antibiotic treatment in the setting of SBP $(8.3 \% v 30.6 \%$ with antibiotics alone; $\mathrm{P}=0.01)$ and may reduce overall mortality $(16 \% v$ $35.4 \%$; odds ratio $0.34,0.19$ to 0.60$).^{7374}$ Albumin administration in patients with infections other than SBP may also improve circulatory function and delay the development of renal dysfunction, ${ }^{75}$ but it has not been shown to prevent AKI-HRS or improve survival. ${ }^{76-78}$

Long term use of weekly albumin in patients with decompensated cirrhosis and ascites has been assessed in a large RCT $(n=431)$. Compared with standard of care, the addition of weekly albumin for 18 months improved overall survival $(77 \% \mathrm{v}$ $66 \% ; \mathrm{P}=0.028)$ and also reduced the incidence of hepatorenal syndrome (odds ratio 0.39, 0.19 to $0.76) .{ }^{79}$ In contrast, a similar trial evaluating the long term use of albumin and midodrine in 196 patients with decompensated cirrhosis on the waitlist for liver transplantation failed to show a survival benefit at one year, and complications of cirrhosis were not prevented. However, in this latter study only a small number of patients completed a full year on the study and the median length of treatment was only 80 days. $^{80}$ The forthcoming PRECIOSA12 (Effects of Long term Administration of Human Albumin in Subjects With Decompensated Cirrhosis and Ascites) trial will hopefully elucidate the role of long term albumin use in this population.

Antibiotic prophylaxis in patients at risk of SBP, as determined by low ascitic fluid protein ( $<1.5 \mathrm{mg} / \mathrm{dL}$ ) associated with liver and/or kidney dysfunction (bilirubin $>3 \mathrm{mg} / \mathrm{dL}$, serum sodium $<130 \mathrm{mEq} / \mathrm{L}$, Child-Turcotte-Pugh score $>10$, and/ or serum creatinine $>1.2 \mathrm{mg} / \mathrm{dL}$ ), not only prevents development of SBP but also significantly reduces the risk of AKI-HRS and overall mortality. ${ }^{81} 82$

Post-paracentesis circulatory dysfunction occurs after large volume paracenteses ( $\geq 4-5 \mathrm{~L})$ and is associated with hypotension, hyponatremia, and increased risk of AKI-HRS. ${ }^{83}$ Albumin administration following a large volume paracentesis significantly reduces this risk and improves overall survival in these patients. ${ }^{84} 85$ This protective effect seems to be unique to albumin, compared with other volume expanders, ${ }^{85}$ which suggests an additional benefit of albumin beyond simply volume expansion. ${ }^{86}$ Albumin has important antioxidant and antiinflammatory properties and helps to stabilize endothelial function. ${ }^{87} 88$ Moreover, human albumin is able to bind and potentially inactivate endotoxins (lipopolysaccharides) and so may reduce their negative effect on circulatory and kidney functions. ${ }^{89}$ Given its potential immunomodulatory effects, ${ }^{90}$ albumin is being investigated in an RCT for prevention of infection in cirrhosis. ${ }^{91}$

\section{Management}

The updated diagnostic criteria, with removal of a minimum serum creatinine concentration, allow for earlier diagnosis and treatment of AKI-HRS. Rather than waiting for a doubling of creatinine to reach 2.5 $\mathrm{g} / \mathrm{dL}$, drug treatment may now be started immediately after an unsuccessful fluid challenge. This is likely to result in higher reversal rates and better outcomes, as response to vasoconstrictors is dependent on the serum creatinine concentration at the start of treatment. ${ }^{22}$ Nevertheless, AKI stage $1 \mathrm{~A}$ (serum creatinine $<1.5 \mathrm{~g} / \mathrm{dL}$ ) is most often secondary to hypovolemia and is expected to resolve in more than $90 \%$ of patients at this stage, compared with a half of patients with stage $1 \mathrm{~B}$ disease (serum creatinine $\geq 1.5 \mathrm{~g} / \mathrm{dL}$ ). ${ }^{354}$ Therefore, European Association for the Study of the Liver (EASL) guidelines recommend reserving the use of vasoconstrictors for patients with AKI-HRS stage $1 \mathrm{~B}$ or greater (fig 3). ${ }^{92}$ However, in most countries, the use of vasoconstrictors is indicated for hepatorenal syndrome type 1 , based on the old definition, and the use of vasoconstrictors in patients with creatinine below $2.5 \mathrm{mg} / \mathrm{dL}$ is considered off-label.

Once a diagnosis of AKI is made, management of hepatorenal syndrome starts with a fluid challenge 
of $20-25 \%$ intravenous albumin at $1 \mathrm{~g} / \mathrm{kg} / \mathrm{day}$ for two days and withdrawal of diuretics. This is not only needed to rule out pre-renal azotemia but also promotes early plasma volume expansion in the setting of reduced EABV. This initial phase also includes temporary discontinuation of non-selective $\beta$ blockers given their negative inotropic effect, which reduces cardiac output. ${ }^{93} 94$ These should be carefully reinstituted once renal function and mean arterial pressure (MAP) improve. ${ }^{93}$

The specific treatment of AKI-HRS comprises vasoconstrictors in combination with albumin infusion and reversal of precipitant factors. Bacterial infections, particularly SBP, should be ruled out by blood, urine, and ascitic fluid cultures and a chest radiograph. Although antibiotics may help to prevent development of AKI-HRS, ${ }^{819596}$ their benefit in patients with established AKI-HRS in the absence of infection has not been demonstrated.

\section{Vasoconstrictors}

Splanchnic vasoconstriction in patients with cirrhosis results in a reduction in portal pressure and an increase in EABV and renal blood flow, especially when combined with intravenous administration of albumin. Renal perfusion directly correlates with changes in MAP and is negatively affected by intra-abdominal pressure driven by ascites. A significant increase in MAP promoted by the use of vasoconstrictors is associated with a higher likelihood of reversal of hepatorenal syndrome. ${ }^{97}$

Several RCTs have confirmed the efficacy of vasoconstrictors, which represent the mainstay treatment of AKI-HRS. ${ }^{98}$ The available options include terlipressin, noradrenaline, and the combination of midodrine plus octreotide.

Terlipressin is not yet available in North America but can be prescribed to treat AKI-HRS in many European and Asian countries. Terlipressin, a synthetic vasopressin analog with predominant vasopressin $1 \mathrm{~A}$ receptor effect, acts primarily as a splanchnic vasoconstrictor. ${ }^{99}$ In addition, terlipressin activates vasopressin $1 \mathrm{~B}$ receptors, which stimulate release of adrenocorticotropic hormone and cortisol and might counteract the relative adrenal insufficiency commonly observed in patients with decompensated cirrhosis. ${ }^{100}$ Furthermore, terlipressin shows greater efficacy in reversal of AKI-HRS in patients with a systemic inflammatory response, ${ }^{101}$ which may relate to indirect vasopressin mediated anti-inflammatory effects. ${ }^{102}$ An agent with selective vasopressin 1 activity is preferable in patients with cirrhosis to

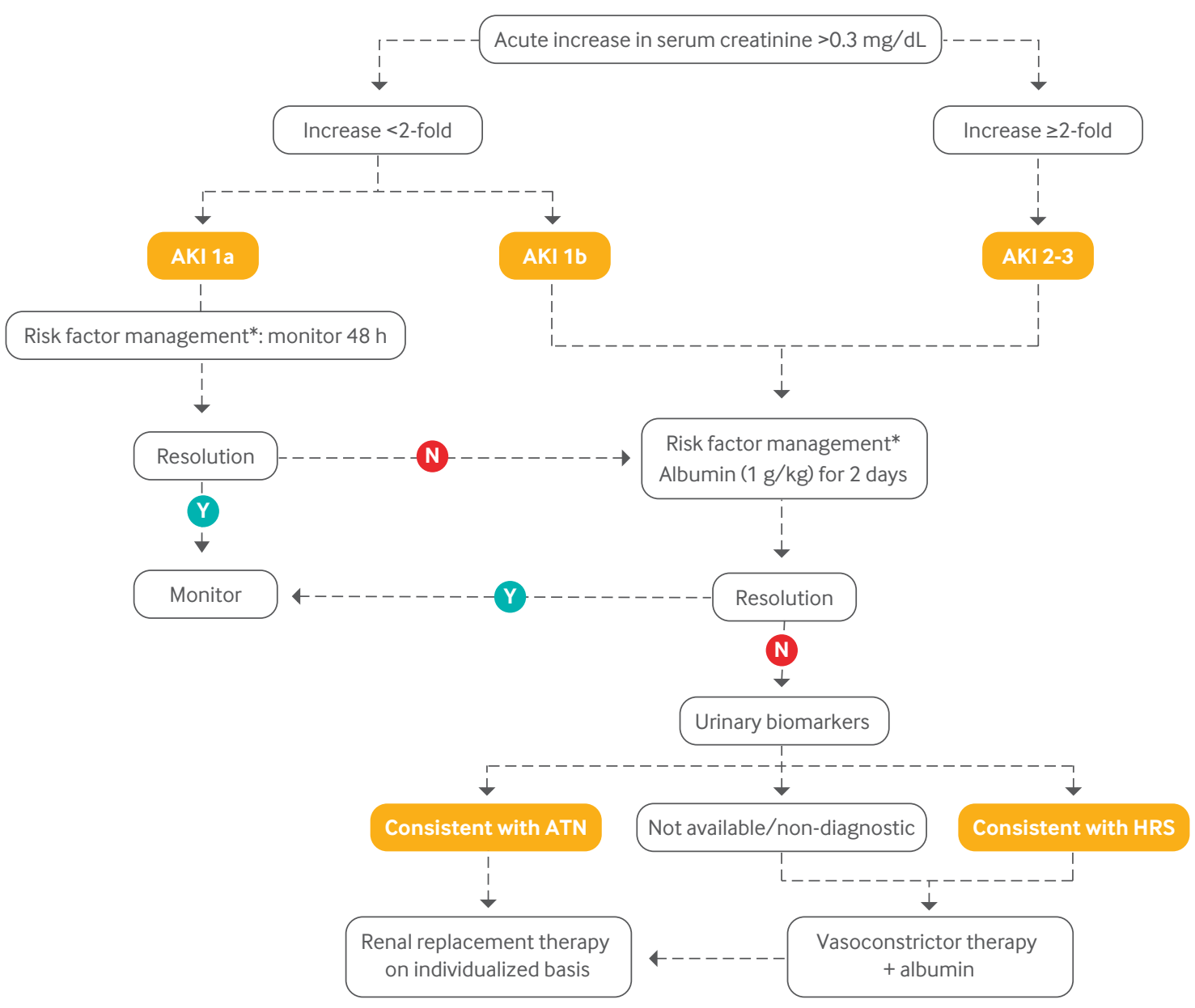

Fig 3 | Algorithm for management of acute kidney injury (AKI) in patients with cirrhosis. ATN=acute tubular necrosis; HRS=hepatorenal syndrome. *Risk factor management: hold nephrotoxic drugs/ $\beta$ blockers, withdraw diuretics, treat infections, plasma volume expansion as needed 
prevent unwanted solute-free water absorption and consequent worsening hyponatremia and volume overload induced by renal vasopressin 2 receptor activation. ${ }^{103}$ Because terlipressin is also a modest vasopressin 2 receptor agonist, ${ }^{99}$ an acute reduction in serum sodium concentration may occur, although this effect is mainly observed in patients with cirrhosis without ascites treated with terlipressin for variceal bleeding. ${ }^{104} \mathrm{~A}$ novel selective vasopressin $1 \mathrm{~A}$ receptor agonist, selepressin, has recently been investigated as an alternative to vasopressin in management of septic shock and has shown a lower risk of hyponatremia, volume overload, and pulmonary edema in animal models of sepsis. ${ }^{105} 106$ The role of selepressin in hepatorenal syndrome warrants further study.

Norepinephrine (intravenous) and midodrine (oral) are systemic vasoconstrictors through activation of $\alpha-1$ adrenergic receptors on vascular smooth muscle cells. Octreotide, a somatostatin analog, acts by inhibiting secretion of glucagon, a splanchnic vasodilator, and is a direct mesenteric vasoconstrictor. ${ }^{107}$ However, the effect of octreotide in patients with cirrhosis is dampened by antagonistic effects of local nitric oxide release, ${ }^{108}$ and octreotide alone has limited benefit in hepatorenal syndrome. ${ }^{109}$ Midodrine monotherapy also does not improve renal function in patients with hepatorenal syndrome despite its hemodynamic effects. ${ }^{110}$ In contrast, a combination of octreotide and midodrine has potential benefit in hepatorenal syndrome and has become the standard of care in countries where terlipressin is not yet approved. ${ }^{111112}$

\section{Efficacy}

Comparative studies (some of them open label) evaluating terlipressin, norepinephrine, and/or octreotide/midodrine have found terlipressin, in combination with intravenous albumin, to be the most effective drug treatment for AKI-HRS (table 1). ${ }^{23}$ 113-122 The efficacy of terlipressin plus albumin in achieving complete reversal of hepatorenal syndrome, defined as at least 50\% reduction in serum creatinine to a final value below $1.5 \mathrm{mg} / \mathrm{dL}$, ranges from $19 \%$ to $56 \%$ compared with $3-14 \%$ with albumin alone. ${ }^{23} 101115118121$ Conversely, administration of terlipressin alone is markedly inferior to a combination of terlipressin and albumin (complete hepatorenal syndrome reversal rates of $25 \%$ and $77 \%$, respectively). ${ }^{123}$ Two large European trials and one North American trial have shown efficacy for terlipressin. ${ }^{23} 115124$ However, in the REVERSE study, a large multicenter phase III trial, terlipressin led to complete reversal of hepatorenal syndrome in only $19.6 \%$ of patients compared with $13.1 \%$ in the placebo group $(\mathrm{P}=0.22) .{ }^{116}$ One of the potential reasons for the discrepant results was the requirement for a confirmatory creatinine concentration below $1.5 \mathrm{mg} / \mathrm{dL} 48$ hours after initial hepatorenal syndrome reversal, which was not available in many patients owing to discharge from hospital or transplantation. Another reason could be the short duration of treatment with terlipressin in a large number of patients. This has led to the execution of yet another RCT in North America designed to overcome the methodological obstacles encountered in the REVERSE trial. The CONFIRM study has been published only in abstract form. The verified hepatorenal syndrome reversal rate with terlipressin plus albumin was $29.1 \%$ compared with $15.8 \%$ with albumin plus placebo $(\mathrm{P}<0.012) .{ }^{117}$

Norepinephrine is also effective and safe in AKIHRS, ${ }^{125}$ with similar rates of hepatorenal syndrome reversal to terlipressin in small randomized studies, ranging between 39\% and 70\%. ${ }^{118-120}$ Norepinephrine is less expensive than terlipressin; however, central line placement and admission to an intensive care unit are needed for administration, which may offset the cost benefit. Terlipressin may be given through a peripheral line on the medical floor. ${ }^{119}$

Only one study has directly compared combination midodrine/octreotide with terlipressin. ${ }^{121}$ The complete response rate for midodrine/octreotide was only $4.8 \%$ compared with $55.5 \%$ with terlipressin, and the overall response (complete or partial) rates were $28.6 \%$ and $70.4 \%$, respectively. Although no placebo controlled studies have been done with either norepinephrine or midodrine/octreotide, a recent network meta-analysis has allowed for indirect comparisons across trials. Compared with placebo, combination midodrine/octreotide was not significantly superior in achieving reversal of hepatorenal syndrome (odds ratio 0.44, 0.06 to 3.23), whereas norepinephrine and terlipressin were both superior to midodrine/octreotide and placebo and were equally effective. ${ }^{98}$

\section{Side effects}

The most common side effects of terlipressin are diarrhea and abdominal pain, reported in 10-20\% of patients overall. Discontinuation of terlipressin due to serious adverse events is needed in 4-22\% (median $8 \%$ ) of patients, with a rate of peripheral ischemic events between $4 \%$ and $13 \%$. The rate of myocardial infarction or intestinal ischemia ranges from $2 \%$ to $13 \% .^{98}$ Pulmonary edema may occur in patients with hepatorenal syndrome treated with terlipressin and albumin, and volume status should be carefully monitored in these patients. ${ }^{116}$ Continuous terlipressin infusion is associated with a lower rate of adverse events compared with bolus administration, likely owing to lower dosing needed. ${ }^{124}$ Nevertheless, patients should be monitored at least twice daily for signs of ischemia in skin, tongue, and fingers while on therapy, and terlipressin should be avoided in patients with a history of coronary artery disease or peripheral vascular disease. ${ }^{92}$ Discontinuation of treatment due to adverse events is less common with norepinephrine and midodrine/octreotide; however, tachyarrhythmias or bradycardia can be seen (table 2). ${ }^{121}$

\section{Predictors of treatment response}

Several factors have been shown to negatively affect response of hepatorenal syndrome to drug 


\begin{tabular}{|c|c|c|c|c|}
\hline Study & Trial design & Drug comparisons (No of patients) & No (\%) HRS reversal & No (\%) mortality \\
\hline \multicolumn{5}{|c|}{ Terlipressin versus placebo/control } \\
\hline Solanki et al, $2003^{113}$ & $\begin{array}{l}\text { Single center, single blind, } \\
\text { placebo controlled }\end{array}$ & $\begin{array}{l}\text { Terlipressin } 1 \mathrm{mg} \text { every } 12 \mathrm{~h} \text { for } 15 \text { days }(\mathrm{n}=12) \mathrm{v} \\
\text { placebo }(\mathrm{n}=12)\end{array}$ & NA & $\begin{array}{l}\text { Terlipressin } 7 / 12(58.3) \mathrm{v} \\
\text { placebo } 12 / 12(100)\end{array}$ \\
\hline Neri et al, $2008^{114}$ & Single center, open label & $\begin{array}{l}\text { Terlipressin } 1 \text { mg every } 8 \text { h for } 5 \text { days followed by } 0.5 \\
\text { mg every } 8 \text { h for } 14 \text { days }(n=26) v \text { albumin only for } 15 \\
\text { days }(n=26)\end{array}$ & $\begin{array}{l}\text { Terlipressin 21/26(80) } v \\
\text { control 5/26 (19) }\end{array}$ & $\begin{array}{l}\text { Terlipressin } 7 / 26(26.9) v \\
\text { control: } 15 / 26(57.7)\end{array}$ \\
\hline Sanyal et al, $2008^{115}$ & $\begin{array}{l}\text { Multicenter, double blind, } \\
\text { placebo controlled }\end{array}$ & $\begin{array}{l}\text { Terlipressin } 1 \mathrm{mg} \text { every } 6 \mathrm{~h} \text { up to } 2 \mathrm{mg} \text { every } 6 \text { hours for } \\
14 \text { days }(\mathrm{n}=56) \vee \text { placebo for } 14 \text { days }(\mathrm{n}=56)\end{array}$ & $\begin{array}{l}\text { Terlipressin 19/56 (33.9) } v \\
\text { placebo } 7 / 56(12.5)\end{array}$ & $\begin{array}{l}\text { Terlipressin 32/56(57.1) } v \\
\text { placebo } 35 / 56(62.5)\end{array}$ \\
\hline Martin-Llahi et al, $2008^{23}$ & Multicenter, open label & $\begin{array}{l}\text { Terlipressin } 1 \mathrm{mg} \text { every } 4 \mathrm{~h} \text { up to } 2 \mathrm{mg} \text { every } 4 \mathrm{~h} \text { for } 15 \\
\text { days }(\mathrm{n}=17) \mathrm{v} \text { albumin only daily for } 15 \text { days }(\mathrm{n}=18)\end{array}$ & $\begin{array}{l}\text { Terlipressin } 6 / 17(35.3) v \\
\text { control } 2 / 18(11.1)\end{array}$ & $\begin{array}{l}\text { Terlipressin 17/23 (73.9) } v \\
\text { control: } 19 / 23(82.6)\end{array}$ \\
\hline Boyer et al, $2016^{116}$ & $\begin{array}{l}\text { Multicenter, double blind, } \\
\text { placebo controlled }\end{array}$ & $\begin{array}{l}\text { Terlipressin } 1 \mathrm{mg} \text { every } 6 \mathrm{~h} \text { up to } 2 \mathrm{mg} \text { every } 6 \mathrm{~h} \text { for } 14 \\
\text { days }(\mathrm{n}=97) \mathrm{v} \text { placebo for } 14 \text { days }(\mathrm{n}=99)\end{array}$ & $\begin{array}{l}\text { Terlipressin 19/97 (19.6) v } \\
\text { placebo } 13 / 99(13.1)\end{array}$ & $\begin{array}{l}\text { Terlipressin 32/97 (33) } v \\
\text { placebo: } 35 / 99(35.3)\end{array}$ \\
\hline Wong et al, $2019^{\star 117}$ & $\begin{array}{l}\text { Multicenter, double blind, } \\
\text { placebo controlled }\end{array}$ & $\begin{array}{l}\text { Terlipressin } 1 \text { mg every } 6 \text { h until verified HRS reversal or } \\
\text { for maximum } 14 \text { days }(n=199) \text { v placebo until verified } \\
\text { HRS reversal or for maximum } 14 \text { days }(n=101)\end{array}$ & $\begin{array}{l}\text { Terlipressin 58/199(29.1) v } \\
\text { placebo } 16 / 101(15.8)\end{array}$ & $\begin{array}{l}\text { Terlipressin 145/199 (72.9) } \\
\text { v placebo } 72 / 101(71.3)\end{array}$ \\
\hline \multicolumn{5}{|c|}{ Terlipressin versus norepinephrine } \\
\hline Alessandria et al, $2007^{118}$ & Single center, open label & $\begin{array}{l}\text { Terlipressin } 1 \text { mg every } 4 \text { h up to } 2 \text { mg every } 4 \mathrm{~h} \\
\text { until HRS reversal or for maximum } 14 \text { days }(n=4) v \\
\text { norepinephrine } 0.1 \mu \mathrm{g} / \mathrm{kg} / \mathrm{min} \text { up to } 0.7 \mu \mathrm{g} / \mathrm{kg} / \mathrm{min} \text { until } \\
\text { HRS reversal or maximum } 14 \text { days }(\mathrm{n}=5)\end{array}$ & $\begin{array}{l}\text { Terlipressin } 3 / 4(75) v \\
\text { norepinephrine } 4 / 5(80)\end{array}$ & $\begin{array}{l}\text { Terlipressin } 1 / 4(25) v \\
\text { norepinephrine } 1 / 5(20)\end{array}$ \\
\hline Sharma et al, $2008^{119}$ & Single center, open label & $\begin{array}{l}\text { Terlipressin } 0.5 \mathrm{mg} \text { every } 6 \mathrm{~h} \text { up to } 2 \mathrm{mg} \text { every } 6 \mathrm{~h} \text { for } 15 \\
\text { days }(\mathrm{n}=20) v \text { norepinephrine } 0.5 \mathrm{mg} / \mathrm{h} \text { up to } 3 \mathrm{mg} / \mathrm{h} \text { for } \\
15 \text { days }(\mathrm{n}=20)\end{array}$ & $\begin{array}{l}\text { Terlipressin 8/20 (40) } v \\
\text { norepinephrine 10/20 (50) }\end{array}$ & $\begin{array}{l}\text { Terlipressin 9/20 (45) } v \\
\text { norepinephrine } 9 / 20(45)\end{array}$ \\
\hline Singh et al, $2012^{120}$ & Single center, open label & $\begin{array}{l}\text { Terlipressin } 0.5 \text { mg every } 6 \text { h up to } 2 \text { mg every } 6 \mathrm{~h} \\
\text { until HRS reversal or for maximum } 14 \text { days ( } \mathrm{n}=23 \text { ) } \\
v \text { norepinephrine } 0.5 \mathrm{mg} / \mathrm{h} \text { up to } 3 \mathrm{mg} / \mathrm{h} \text { until HRS } \\
\text { reversal or for maximum } 14 \text { days }(\mathrm{n}=23 \text { ) }\end{array}$ & $\begin{array}{l}\text { Terlipressin } 9 / 23(39.1) \\
\text { v norepinephrine } 10 / 23 \\
(43.5)\end{array}$ & $\begin{array}{l}\text { Terlipressin } 16 / 23(69.5) \mathrm{v} \\
\text { norepinephrine } 15 / 23(65.2)\end{array}$ \\
\hline \multicolumn{5}{|c|}{ Terlipressin versus midodrine plus octreotide } \\
\hline Cavallin et al, $2015^{121}$ & Multicenter, open label & $\begin{array}{l}\text { Terlipressin } 3-12 \text { mg per } 24 \text { h until HRS reversal or for } \\
\text { maximum } 14 \text { days }(n=27) v \text { midodrine } 7.5-12.5 \mathrm{mg} \\
\text { every } 8 \mathrm{~h} \text { orally plus octreotide } 100-200 \mu \mathrm{g} \text { every } 8 \mathrm{~h} \\
\text { subcutaneously until HRS reversal or for maximum of } 14 \\
\text { days }(\mathrm{n}=22)\end{array}$ & $\begin{array}{l}\text { Terlipressin } 15 / 27(55.5) v \\
\text { midodrine plus octreotide } \\
1 / 22(4.5)\end{array}$ & $\begin{array}{l}\text { Terlipressin } 8 / 27(29.6) v \\
\text { midodrine plus octreotide } \\
7 / 22(31.8)\end{array}$ \\
\hline
\end{tabular}

treatment, including model for end stage liver disease (MELD) score, ${ }^{126}$ pretreatment serum creatinine concentration, ${ }^{22} 23$ sepsis, ${ }^{126}$ extrahepatic organ failure, ${ }^{127}$ and systemic inflammation. ${ }^{29}$ Lower serum creatinine concentrations at the start of treatment are associated with higher rates of HRS reversal, whereas only a negligible response is expected when creatinine exceeds $7 \mathrm{~g} / \mathrm{dL}^{22}{ }^{23}$ Thus, earlier diagnosis of AKI-HRS with the elimination of creatinine concentration cut-off, will likely result in higher rates of response to treatment. Total serum bilirubin concentration has also been found to predict response, with an area under the receiver operating characteristic curve of $0.77 \quad(\mathrm{P}<0.0001)$ for a bilirubin cut-off of $10 \mathrm{mg} / \mathrm{dL}$. ${ }^{46}$ These findings suggest the presence of structural damage.

Finally, response to treatment with vasoactive agents directly correlates with sustained increase in MAP. $^{97}$ Independent of the agents used, improvement in renal function is preceded by a sustained rise in MAP by $5-10 \mathrm{~mm} \mathrm{Hg}$ on average from baseline. ${ }^{2246111}$

\section{Albumin}

Albumin infusion is essential for effective management of AKI-HRS. Several studies provide supportive evidence for a multifaceted mode of action by albumin, which may also include volume expansion and positive cardiac inotropic effect, ${ }^{128}$ as well as antioxidant and immunomodulatory properties. $^{88} 129130$ In a single non-randomized study comparing terlipressin plus albumin versus terlipressin alone, the combination with albumin resulted in a significantly higher response $(77 \%$ $v 25 \% ; \mathrm{P}=0.03) .{ }^{123}$ In addition to plasma volume expansion and consequent increase in EABV, albumin has shown several other benefits in hepatorenal syndrome. In a study comparing hydroxyethyl starch, a synthetic colloid, with albumin in patients with SBP, albumin use was associated with lower plasma concentrations of von Willebrand related antigen and factor VIII, suggesting that albumin, but not hydroxyethyl starch, may reduce endothelial activation. $^{86}$

One important property of albumin is its ability to bind a wide range of substances including bile acids, hormones, cytokines, long chain fatty acids, nitric oxide, endotoxin, and other bacterial products. ${ }^{131}$ This is the basis for the advent of molecular absorbent recirculatory systems, a modified dialysis method that clears substances bound to albumin. This results in a significant reduction in serum creatinine concentrations in patients with hepatorenal syndrome. ${ }^{132}$ However, improvement in renal function and systemic hemodynamics is not observed in patients with hepatorenal syndrome refractory to vasoconstrictors, despite reduction in nitric oxide concentrations. ${ }^{133}$ 


\begin{tabular}{|c|c|c|c|c|}
\hline Treatment & Dose & Route & Frequency & Side effects \\
\hline $\begin{array}{l}\text { Midodrine and } \\
\text { octreotide }\end{array}$ & $7.5-15 \mathrm{mg}$ and $100-200 \mu \mathrm{g}$ & $\begin{array}{l}\text { Oral and } \\
\text { subcutaneous }\end{array}$ & Three times daily & $\begin{array}{l}\text { Bradyarrhythmias, paresthesias, abdominal pain, } \\
\text { diarrhea, cholelithiasis, hyperglycemia }\end{array}$ \\
\hline Norepinephrine & $\begin{array}{l}0.5-3 \mathrm{mg} / \mathrm{h} \text {; titrate to achieve } 10 \mathrm{~mm} \mathrm{Hg} \\
\text { increase in mean arterial pressure }\end{array}$ & Intravenous & Continuous infusion & $\begin{array}{l}\text { Nausea, vomiting, anxiety, } \\
\text { cardiac dysrhythmias }\end{array}$ \\
\hline Terlipressin & $\begin{array}{l}1 \mathrm{mg} \text {; titrate if no improvement (decrease } \\
\text { in serum creatinine by } 25 \% \text { by day } 3 \text { ) up to } \\
\text { maximum } 12 \mathrm{mg} / \text { day }\end{array}$ & Intravenous & $\begin{array}{l}\text { Every } 4-6 \text { h or } \\
\text { continuous infusion }\end{array}$ & $\begin{array}{l}\text { Diarrhea, abdominal pain, peripheral ischemia, } \\
\text { myocardial infarction, mesenteric ischemia, } \\
\text { pulmonary edema }\end{array}$ \\
\hline
\end{tabular}

\section{Transjugular intrahepatic portosystemic shunt}

The creation of an intrahepatic shunt aimed at reducing portal pressure has shown significant benefit in patients with cirrhosis who cannot tolerate diuretics or have refractory ascites and who have uncontrolled variceal bleeding. ${ }^{134} 135$ However, only a few studies have explored the role of transjugular intrahepatic portosystemic shunt (TIPS) insertion in AKI-HRS, so its use remains investigational in this group. One small non-randomized study showed significant improvement in renal function after TIPS insertion for AKI-HRS, with reduction in plasma renin activity and aldosterone and norepinephrine concentrations. ${ }^{136} \mathrm{~A}$ meta-analysis including nine studies in which 128 patients with hepatorenal syndrome underwent TIPS insertion (77 patients with hepatorenal syndrome type 1 and 51 patients with type 2), showed significant improvement in serum creatinine, serum sodium, and urine output. ${ }^{137}$ Patients with markedly elevated bilirubin, active infection, or overt hepatic encephalopathy were excluded, so the role of TIPS in hepatorenal syndrome may be limited to a highly selected group of patients. On the other hand, TIPS may have a greater

\begin{tabular}{|c|}
\hline Strength of recommendation \\
\hline Weak \\
\hline Weak \\
\hline Weak \\
\hline Strong \\
\hline Strong \\
\hline Strong \\
\hline
\end{tabular}
but its efficacy is much lower than that of terlipressin

According to the new definition of HRS-AKI, complete response to treatment should be defined by a final SCr within

$0.3 \mathrm{mg} / \mathrm{dL}(26.5 \mu \mathrm{mol} / \mathrm{L})$ from the baseline value, while partial response should be defined by the regression of AKI stage to a

final $\mathrm{SCr} \geq 0.3 \mathrm{mg} / \mathrm{dL}(26.5 \mu \mathrm{mol} / \mathrm{L})$ from the baseline value

Adverse events related to terlipressin or noradrenaline include ischemic and cardiovascular events. Thus, a careful clinical screening including Strong electrocardiography is recommended before starting the treatment. Patients can be treated on a regular ward, but the decision to transfer to higher dependency care should be case based. For the duration of treatment, close monitoring of patients is important. According to the type and severity of side effects, treatment should be modified or discontinued

In cases of recurrence of HRS-AKI on cessation of treatment, a repeat course of therapy should be given

Terlipressin plus albumin is also effective in the treatment of HRS outside the criteria of AKI (HRS-NAKI), formerly known as HRS type II. Strong

Unfortunately, recurrence after the withdrawal of treatment is the norm, and data on the effect of the treatment on long term clinical outcome are controversial, particularly from the perspective of LT. As such, vasoconstrictors and albumin are not recommended in this clinical scenario

Insufficient data exist to allow TIPS to be advocated in HRS-AKI, but it could be suggested in selected patients with HRS-NAKI

LT is the best therapeutic option for patients with HRS regardless of the response to drug therapy

The decision to initiate RRT should be based on the individual severity of illness

The indication for liver-kidney transplantation remains controversial. This procedure should be considered in patients with significant CKD or with sustained AKI including HRS-AKI with no response to drug therapy

Albumin (1.5 g/ $/ \mathrm{kg}$ at diagnosis and $1 \mathrm{~g} / \mathrm{kg}$ on day 3$)$ should be given in patients with SBP to prevent AKI 
protective effect as shown by reduced incidence of hepatorenal syndrome in patients with cirrhosis and diuretic refractory ascites post-TIPS. ${ }^{134}$

\section{Renal replacement therapy}

Renal replacement therapy (RRT) may be indicated for patients with AKI-HRS unresponsive to drug treatment and with volume overload, uremia, or electrolyte derangements; however, RRT does not improve survival in hepatorenal syndrome, ${ }^{138}$ and it should be reserved for use as a bridge to transplantation, when transplantation is an option. ${ }^{139}$ Short term mortality in patients with cirrhosis and AKI who are ineligible for transplantation approaches 90\%, ${ }^{140} 141$ independently of the cause of AKI. ${ }^{142}$ Therefore, RRT is often futile in this setting.

\section{Liver transplantation}

The functional nature of hepatorenal syndrome means that improvement in renal function is expected with liver transplantation, which remains the optimal treatment of AKI-HRS whenever feasible. ${ }^{143-145}$ However, kidney recovery is not universal and is dependent on multiple factors, particularly duration of kidney injury. ${ }^{146}$ In such cases, simultaneous liver-kidney transplantation is recommended rather than liver transplantation alone. However, accurately predicting native kidney recovery after liver transplantation remains a challenge. In the US, the Organ Procurement and Transplantation Network policy for simultaneous liver-kidney organ allocation requires sustained AKI defined as need for dialysis or measured or calculated creatinine clearance or GFR of $25 \mathrm{~mL} / \mathrm{min}$ or below for a minimum of six consecutive weeks. ${ }^{147}$ Despite best efforts, almost $10 \%$ of patients with either AKI or CKD who receive a liver alone may have persistent or progressive renal failure after transplant. ${ }^{148}$ Patients with ATN are at particularly increased risk of chronic kidney disease (stage 4 or 5) post-transplant, and the lack of ideal biomarkers often results in misdiagnosis. ${ }^{149}$ This has led to a consensus "safety net" for prioritization of liver recipients on the kidney waiting list if they are registered within a year after their liver transplant. ${ }^{150}$

\section{Guidelines}

Prevention, diagnosis, and management of hepatorenal syndrome are included in both the American Association for the Study of Liver Diseases (AASLD) and the EASL guidelines on the management of patients with ascites or decompensated cirrhosis (table 3). ${ }^{92} 151$ The AASLD guidelines were last updated in 2012 and do not contain the most up-to-date diagnostic criteria and classification of hepatorenal syndrome adopted in 2015. In contrast, the European guidelines published in 2018 incorporate the recent changes, including the exclusion of a creatinine cut-off for diagnosis of HRS-AKI. This important change now allows for earlier treatment of HRS-AKI with vasoactive agents as discussed earlier. Another important difference between the two guidelines is the options for medical management of hepatorenal syndrome. Terlipressin plus albumin is considered first line treatment of HRS-AKI according to the EASL guidelines; however, terlipressin is not yet available in the US, and management of HRS-AKI is limited to albumin, octreotide plus midodrine, or norepinephrine as per the American guidelines.

\section{Emerging treatments}

New treatment options are urgently needed, as efficacy of vasoconstrictors and albumin is limited to less than half of patients with AKI-HRS. Serelaxin (recombinant human relaxin-2) is novel agent that acts on renal vasculature and results in increased renal blood flow, reduced renal vascular resistance, and reversal of endothelial dysfunction. ${ }^{152}$ Furthermore, serelaxin has been shown to reduceintrahepatic vascular resistance in animal models of cirrhosis, thereby ameliorating portal hypertension. ${ }^{153}$ An exploratory randomized phase II study showed an increase in total renal arterial blood flow by $65 \%$ in patients with compensated cirrhosis treated with serelaxin. ${ }^{154}$ No studies have been reported in patients with hepatorenal syndrome.

In addition to vasoactive drugs, treatments targeting systemic inflammation, including DAMPs, PAMPs, and downstream signaling, could be explored in hepatorenal syndrome. One small randomized study showed that pentoxifylline, a phosphodiesterase inhibitor with anti-TNF- $\alpha$ activity and anti-inflammatory effect, is safe in patients with AKI-HRS. However, the study failed to show an added benefit compared with standard of care alone (midodrine, octreotide, and albumin). ${ }^{155}$ The role of serelaxin and novel therapies targeting inflammation in the clinical management of AKI-HRS needs to be explored in future studies.

\section{Conclusions}

Despite advances in biomarker discovery and evolving definitions of hepatorenal syndrome, much of its pathophysiology beyond circulatory dysfunction still remains to be uncovered. Systemic inflammation, in the presence or absence of infection, remains an untapped territory in the understanding of hepatorenal syndrome. Novel translational experimental models of hepatorenal syndrome are needed to fill this gap and, hopefully, will help to identify novel targets for potential drug development. In the meantime, emphasis should be on preventive measures for patients at risk of hepatorenal syndrome, including appropriate antibiotic prophylaxis and albumin use when indicated. For patients with established hepatorenal syndrome, terlipressin with albumin is considered first line medical treatment; however, liver transplantation remains the optimal treatment, and timely referral for transplant evaluation is crucial to avoid permanent kidney damage and the need for simultaneous liver and kidney transplant. 


\section{GLOSSARY OF ABBREVIATIONS}

- AASLD-American Association for the Study of Liver Diseases

- AKI-acute kidney injury

- AKIN-Acute Kidney Injury Network

- ATN-acute tubular necrosis

- CKD-chronic kidney disease

- DAMP-damage associated molecular pattern

- EABV-effective arterial blood volume

- EASL-European Association for the Study of the Liver

- eGFR-estimated glomerular filtration rate

- FeNa-fractional excretion of sodium

- GFR-glomerular filtration rate

- HRS-hepatorenal syndrome

- ICA-International Club of Ascites

- KDIGO-Kidney Disease Improving Global Outcome

- MAP-mean arterial pressure

- MELD-model for end-stage liver disease

- NAKI-non-acute kidney injury

- NGAL-neutrophil gelatinase associated lipocalin

- PAMP-pathogen associated molecular pattern

- RAI-relative adrenal insufficiency

- RCT-randomized clinical trial

- RIFLE-risk, injury, failure, loss, and end stage kidney disease

- RRT-renal replacement therapy

- SBP-spontaneous bacterial peritonitis

- TIPS-transjugular intrahepatic portosystemic shunt

- TLR-toll-like receptor

- TNF-tumor necrosis factor
2 Wu CC, Yeung LK, Tsai WS, et al. Incidence and factors predictive of acute renal failure in patients with advanced liver cirrhosis. Clin Nephrol 2006;65:28-33. doi:10.5414/CNP65028

3 Piano S, Rosi S, Maresio G, et al. Evaluation of the Acute Kidney Injury Network criteria in hospitalized patients with cirrhosis and ascites. J Hepatol 2013:59:482-9. doi:10.1016/i.jhep.2013.03.039

4 Sujan R, Cruz-Lemini M, Altamirano J, et al. A Validated Score Predicts Acute Kidney Injury and Survival in Patients With Alcoholic Hepatitis. Liver Transpl 2018;24:1655-64. doi:10.1002/lt.25328

5 Sherman DS, Fish DN, Teitelbaum I. Assessing renal function in cirrhotic patients: problems and pitfalls. Am J Kidney Dis 2003;41:269-78. doi:10.1053/ajkd.2003.50035

6 Caregaro L, Menon F, Angeli P, et al. Limitations of serum creatinine level and creatinine clearance as filtration markers in cirrhosis. Arch Intern Med 1994;154:201-5. doi:10.1001/ archinte 1994.00420020117013

7 Mindikoglu AL, Dowling TC, Weir MR, Seliger SL, Christenson RH, Magder LS. Performance of chronic kidney disease epidemiology collaboration creatinine-cystatin C equation for estimating kidney function in cirrhosis. Hepatology 2014;59:1532-42. doi:10.1002/ hep. 26556

8 Bellomo R, Ronco C, Kellum JA, Mehta RL, Palevsky P, Acute Dialysis Quality Initiative workgroup. Acute renal failure - definition, outcome measures, animal models, fluid therapy and information technology needs: the Second International Consensus Conference of the Acute Dialysis Quality Initiative (ADQI) Group. Crit Care 2004;8:R204-12. doi:10.1186/cc2872

9 Mehta RL, Kellum JA, Shah SV, et al, Acute Kidney Injury Network. Acute Kidney Injury Network: report of an initiative to improve outcomes in acute kidney injury. Crit Care 2007;11:R31. doi:10.1186/cc5713

10 Lassnigg A, Schmidlin D, Mouhieddine M, et al. Minimal changes of serum creatinine predict prognosis in patients after cardiothoracic surgery: a prospective cohort study. I Am Soc Nephrol 2004;15:1597-605. doi:10.1097/01. ASN.0000130340.93930.DD

11 Chertow GM, Burdick E, Honour M, Bonventre JV, Bates DW. Acute kidney injury, mortality, length of stay, and costs in hospitalized patients. J Am Soc Nephrol 2005;16:3365-70. doi:10.1681/ ASN.2004090740

12 Summary of Recommendation Statements. Kidney Int Suppl (2011) 2012;2:8-12. doi:10.1038/kisup.2012.7

13 Arroyo V, Ginès $\mathrm{P}$, Gerbes AL, et al. Definition and diagnostic criteria of refractory ascites and hepatorenal syndrome in cirrhosis. International Ascites Club. Hepatology 1996;23:164-76. doi:10.1002/hep.510230122

14 Belcher JM, Garcia-Tsao G, Sanyal AJ, et al, TRIBE-AKI Consortium. Association of AKI with mortality and complications in hospitalized patients with cirrhosis. Hepatology 2013;57:753-62. doi:10.1002/ hep. 25735

15 Tsien CD, Rabie R, Wong F. Acute kidney injury in decompensated cirrhosis. Gut 2013;62:131-7. doi:10.1136/gutjnl-2011-301255

16 de Carvalho JR, Villela-Nogueira CA, Luiz RR, et al. Acute kidney injury network criteria as a predictor of hospital mortality in cirrhotic patients with ascites. J Clin Gastroenterol 2012;46:e21-6. doi:10.1097/MCG.0b013e31822e8e12

17 Wong F, O'Leary JG, Reddy KR, et al, North American Consortium for Study of End-Stage Liver Disease. New consensus definition of acute kidney injury accurately predicts 30-day mortality in patients with cirrhosis and infection. Gastroenterology 2013;145:1280-8.e1. doi:10.1053/j.gastro.2013.08.051

18 Altamirano J, Fagundes C, Dominguez M, et al. Acute kidney injury is an early predictor of mortality for patients with alcoholic hepatitis. Clin Gastroenterol Hepatol 2012;10:65-71.e3. doi:10.1016/j. cgh.2011.09.011

19 Angeli P, Gines P. Wong F, et al, International Club of Ascites. Diagnosis and management of acute kidney injury in patients with cirrhosis: revised consensus recommendations of the International Club of Ascites. Gut 2015;64:531-7. doi:10.1136/ gutinl-2014-308874

20 Amathieu R, Al-Khafaji A, Sileanu FE, et al. Significance of oliguria in critically ill patients with chronic liver disease. Hepatology 2017;66:1592-600. doi:10.1002/hep.29303

21 Angeli P, Garcia-Tsao G, Nadim MK, Parikh CR. News in pathophysiology, definition and classification of hepatorenal syndrome: A step beyond the International Club of Ascites (ICA) consensus document. J Hepatol 2019;71:811-22. doi:10.1016/j. jhep.2019.07.002

22 Boyer TD, Sanyal AJ, Garcia-Tsao G, et al, Terlipressin Study Group. Predictors of response to terlipressin plus albumin in hepatorenal syndrome (HRS) type 1: relationship of serum creatinine to hemodynamics. J Hepatol 2011;55:315-21. doi:10.1016/j. jhep.2010.11.020

23 Martín-Llahí M, Pépin MN, Guevara M, et al, TAHRS Investigators. Terlipressin and albumin vs albumin in patients

Fagundes C, Barreto R, Guevara M, et al. A modified acute kidney injury classification for diagnosis and risk stratification of impairment of kidney function in cirrhosis. J Hepatol 2013;59:474-81. doi:10.1016/j.jhep.2013.04.036 
with cirrhosis and hepatorenal syndrome: a randomized study. Gastroenterology 2008;134:1352-9. doi:10.1053/i. gastro.2008.02.024

24 National Kidney Foundation. K/DOQI clinical practice guidelines for chronic kidney disease: evaluation, classification, and stratification. Am J Kidney Dis 2002;39(Suppl 1):S1-266.

25 Schrier RW, Arroyo V, Bernardi M, Epstein M, Henriksen JH, Rodés J. Peripheral arterial vasodilation hypothesis: a proposal for the initiation of renal sodium and water retention in cirrhosis. Hepatology 1988;8:1151-7. doi:10.1002/hep.1840080532

26 Ruiz-del-Arbol L, Monescillo A, Arocena C, et al. Circulatory function and hepatorenal syndrome in cirrhosis. Hepatology 2005;42:43947. doi:10.1002/hep.20766

27 Varga ZV, Erdelyi K, Paloczi J, et al. Disruption of Renal Arginine Metabolism Promotes Kidney Injury in Hepatorenal Syndrome in Mice. Hepatology 2018:68:1519-33 doi:10.1002/hep.29915

28 Thabut D, Massard J, Gangloff A, et al. Model for end-stage liver disease score and systemic inflammatory response are major prognostic factors in patients with cirrhosis and acute functional renal failure. Hepatology 2007;46:1872-82. doi:10.1002/ hep. 21920

29 Solé C, Solà E, Huelin P, et al. Characterization of inflammatory response in hepatorenal syndrome: Relationship with kidney outcome and survival. Liver Int 2019;39:1246-55. doi:10.1111/ liv. 14037

30 Shah N, Mohamed FE, Jover-Cobos M, et al. Increased renal expression and urinary excretion of TLR4 in acute kidney injury associated with cirrhosis. Liver Int 2013;33:398-409. doi:10.1111/ liv.12047

31 Shah N, Dhar D, El Zahraa Mohammed F, et al. Prevention of acute kidney injury in a rodent model of cirrhosis following selective gut decontamination is associated with reduced renal TLR4 expression. Hepatol 2012:56:1047-53 doi:10.1016/j.jhep.2011.11.024

32 Rivolta R, Maggi A, Cazzaniga M, et al. Reduction of renal cortical blood flow assessed by Doppler in cirrhotic patients with refractory ascites. Hepatology 1998;28:1235-40. doi:10.1002/ hep. 510280510

33 Mindikoglu AL, Dowling TC, Wong-You-Cheong JJ, et al. A pilot study to evaluate renal hemodynamics in cirrhosis by simultaneous glomerular filtration rate, renal plasma flow, renal resistive indices and biomarkers measurements. Am J Nephrol 2014;39:543-52 doi:10.1159/000363584

34 Jang HR, Rabb H. Immune cells in experimental acute kidney injury. Nat Rev Nephrol 2015;11:88-101. doi:10.1038/nrneph.2014.180

35 Jang JY, Kim TY, Sohn JH, et al. Relative adrenal insufficiency in chronic liver disease: its prevalence and effects on long-term mortality. Aliment Pharmacol Ther 2014;40:819-26. doi:10.1111/apt.12891

36 Singh RR, Walia R, Sachdeva N, Bhalla A, Singh A, Singh V. Relative adrenal insufficiency in cirrhotic patients with ascites (hepatoadrenal syndrome). Dig Liver Dis 2018;50:1232-7. doi:10.1016/j. dld.2018.05.011

37 Piano S, Favaretto E, Tonon M, et al. Including Relative Adrenal Insufficiency in Definition and Classification of Acute-on-Chronic Liver Failure. Clin Gastroenterol Hepatol 2020;18:1188-1196.e3. doi:10.1016/j.cgh.2019.09.035

38 Acevedo J, Fernández J, Prado V et al. Relative adrenal insufficiency in decompensated cirrhosis: Relationship to shortterm risk of severe sepsis, hepatorenal syndrome, and death Hepatology 2013;58:1757-65. doi:10.1002/hep.26535

39 Tsai MH, Peng YS, Chen YC, et al. Adrenal insufficiency in patients with cirrhosis, severe sepsis and septic shock. Hepatology 2006;43:673 81. doi:10.1002/hep.21101

40 Kim G, Huh JH, Lee KJ, Kim MY, Shim KY, Baik SK. Relative Adrenal Insufficiency in Patients with Cirrhosis: A Systematic Review and Meta-Analysis. Dig Dis Sci 2017;62:1067-79. doi:10.1007/s10620017-4471-8

41 Marik PE. Adrenal-exhaustion syndrome in patients with liver disease. Intensive Care Med 2006;32:275-80. doi:10.1007/s00134-005 0005-5

42 Bornstein SR. Predisposing factors for adrenal insufficiency. N Engl J Med 2009;360:2328-39. doi:10.1056/NEJMra0804635

43 Fernández J, Escorsell A, Zabalza M, et al. Adrenal insufficiency in patients with cirrhosis and septic shock: Effect of treatment with hydrocortisone on survival. Hepatology 2006;44:1288-95. doi:10.1002/hep.21352

44 Bräsen JH, Mederacke YS, Schmitz I, et al. Cholemic Nephropathy Causes Acute Kidney Injury and Is Accompanied by Loss of Aquaporin 2 in Collecting Ducts. Hepatology 2019;69:2107-19. doi:10.1002/ hep.30499

45 van Slambrouck CM, Salem F, Meehan SM, Chang A. Bile cast nephropathy is a common pathologic finding for kidney injury associated with severe liver dysfunction[published Online First: 2013/03/15]. Kidney Int 2013:84:192-7. doi:10.1038/ki.2013.78.

46 Nazar A, Pereira GH, Guevara M, et al. Predictors of response to therapy with terlipressin and albumin in patients with cirrhosis and type 1 hepatorenal syndrome. Hepatology 2010;51:219-26. doi:10.1002/hep. 23283

47 Barreto R, Fagundes C, Guevara M, et al. Type-1 hepatorenal syndrome associated with infections in cirrhosis: natural history, outcome of kidney function, and survival. Hepatology 2014:59:1505-13. doi:10.1002/hep.26687

48 Krones E, Eller K, Pollheimer MJ, et al. NorUrsodeoxycholic acid ameliorates cholemic nephropathy in bile duct ligated mice. J Hepatol 2017;67:110-9. doi:10.1016/j.jhep.2017.02.019

49 Umgelter A, Reindl W, Wagner KS, et al. Effects of plasma expansion with albumin and paracentesis on haemodynamics and kidney function in critically ill cirrhotic patients with tense ascites and hepatorenal syndrome: a prospective uncontrolled trial. Crit Care 2008;12:R4. doi:10.1186/cc6765

50 Velez JCQ, Petkovich B, Karakala N, Huggins JT. Point-of-Care Echocardiography Unveils Misclassification of Acute Kidney Injury as Hepatorenal Syndrome. Am J Nephrol 2019;50:204-11. doi:10.1159/000501299

51 Lang F, Tschernko E, Schulze E, et al. Hepatorenal reflex regulating kidney function. Hepatology 1991;14:590-4. doi:10.1002/ hep. 1840140403

52 Ming Z, Smyth DD, Lautt WW. Decreases in portal flow trigger a hepatorenal reflex to inhibit renal sodium and water excretion in rats: role of adenosine. Hepatology 2002;35:167-75. doi:10.1053/ jhep.2002.30425

53 Garcia-Tsao G, Parikh CR, Viola A. Acute kidney injury in cirrhosis. Hepatology 2008;48:2064-77. doi:10.1002/hep.22605

54 Huelin P, Piano S, Solà E, et al. Validation of a Staging System for Acute Kidney Injury in Patients With Cirrhosis and Association With Acute-on-Chronic Liver Failure. Clin Gastroenterol Hepatol 2017;15:438-445.e5. doi:10.1016/j.cgh.2016.09.156

55 Dudley FJ, Kanel GC, Wood LJ, Reynolds TB. Hepatorenal syndrome without avid sodium retention. Hepatology 1986;6:248-51. doi:10.1002/hep.1840060216

56 Alsaad AA, Wadei HM. Fractional excretion of sodium in hepatorenal syndrome: Clinical and pathological correlation. World ) Hepatol 2016;8:1497-501. doi:10.4254/wih.v8.i34.1497

57 Carvounis CP, Nisar S, Guro-Razuman S. Significance of the fractional excretion of urea in the differential diagnosis of acute renal failure. Kidney Int 2002;62:2223-9. doi:10.1046/j.1523 1755.2002.00683.x

58 Patidar KR, Kang L, Bajaj JS, Carl D, Sanyal AJ. Fractional excretion of urea: A simple tool for the differential diagnosis of acute kidney injury in cirrhosis. Hepatology 2018;68:224-33. doi:10.1002 hep. 29772

59 Francoz C, Nadim MK, Durand F Kidney biomarkers in cirrhosis. Hepatol 2016;65:809-24. doi:10.1016/j.jhep.2016.05.025

60 Allegretti AS, Solà E, Ginès P. Clinical application of kidney biomarkers in cirrhosis. Am I Kidney Dis 2020;S02726386(20)30691-0.

61 Fagundes C, Pépin MN, Guevara M, et al. Urinary neutrophil gelatinase-associated lipocalin as biomarker in the differential diagnosis of impairment of kidney function in cirrhosis. J Hepatol 2012;57:267-73. doi:10.1016/j.jhep.2012.03.015

62 Verna EC, Brown RS, Farrand E, et al. Urinary neutrophil gelatinaseassociated lipocalin predicts mortality and identifies acute kidney injury in cirrhosis. Dig Dis Sci 2012;57:2362-70. doi:10.1007/ s10620-012-2180-x

63 Belcher JM, Sanyal AJ, Peixoto AJ, et al, TRIBE-AKI Consortium. Kidney biomarkers and differential diagnosis of patients with cirrhosis and acute kidney injury. Hepatology 2014;60:622-32. doi:10.1002/ hep. 26980

64 Huelin P, Solà E, Elia C, et al. Neutrophil Gelatinase-Associated Lipocalin for Assessment of Acute Kidney Injury in Cirrhosis: A Prospective Study. Hepatology 2019;70:319-33. doi:10.1002/ hep.30592

65 Hamdy HS, El-Ray A, Salaheldin M, et al. Urinary Neutrophil Gelatinase-Associated Lipocalin in Cirrhotic Patients with Acute Kidney Injury. Ann Hepatol 2018;17:624-30. doi:10.5604/01.3001.0012.0931

66 Barreto R, Elia C, Solà E, et al. Urinary neutrophil gelatinaseassociated lipocalin predicts kidney outcome and death in patients with cirrhosis and bacterial infections. J Hepatol 2014;61:35-42. doi:10.1016/j.jhep.2014.02.023

67 Ginès A, Escorsell A, Ginès P, et al. Incidence, predictive factors, and prognosis of the hepatorenal syndrome in cirrhosis with ascites. Gastroenterology 1993;105:229-36. doi:10.1016/00165085(93)90031-7

68 Wong F, Jepsen P, Watson H, Vilstrup H. Un-precipitated acute kidney injury is uncommon among stable patients with cirrhosis and ascites. Liver Int 2018;38:1785-92. doi:10.1111/liv.13738

69 Follo A, Llovet JM, Navasa M, et al. Renal impairment after spontaneous bacterial peritonitis in cirrhosis: incidence, clinical course, predictive factors and prognosis. Hepatology 1994;20:1495501. doi:10.1002/hep.1840200619 
70 Terra C, Guevara M, Torre A, et al. Renal failure in patients with cirrhosis and sepsis unrelated to spontaneous bacterial peritonitis: value of MELD score. Gastroenterology 2005;129:1944-53. doi:10.1053/j.gastro.2005.09.024

71 Fasolato S, Angeli P, Dallagnese L, et al. Renal failure and bacterial infections in patients with cirrhosis: epidemiology and clinical features. Hepatology 2007;45:223-9. doi:10.1002/hep.21443

72 Navasa M, Follo A, Filella X, et al. Tumor necrosis factor and interleukin-6 in spontaneous bacterial peritonitis in cirrhosis: relationship with the development of renal impairment and mortality. Hepatology 1998;27:1227-32. doi:10.1002/hep.510270507

73 Sort P, Navasa M, Arroyo V, et al. Effect of intravenous albumin on renal impairment and mortality in patients with cirrhosis and spontaneous bacterial peritonitis. N Engl J Med 1999;341:403-9. doi:10.1056/NEJM199908053410603

74 Salerno F, Navickis RJ, Wilkes MM. Albumin infusion improves outcomes of patients with spontaneous bacterial peritonitis: a meta-analysis of randomized trials. Clin Gastroenterol Hepatol 2013;11:123-30.e1. doi:10.1016/j.cgh.2012.11.007

75 Thévenot T, Bureau C, Oberti F, et al. Effect of albumin in cirrhotic patients with infection other than spontaneous bacterial peritonitis. A randomized trial. J Hepatol 2015;62:822-30. doi:10.1016/j. jhep.2014.11.017

76 Fernández J, Angeli P, Trebicka J, et al. Efficacy of Albumin Treatment for Patients with Cirrhosis and Infections Unrelated to Spontaneous Bacterial Peritonitis. Clin Gastroenterol Hepatol 2020;18:963-973. e14. doi:10.1016/j.cgh.2019.07.055

77 Guevara M, Terra C, Nazar A, et al. Albumin for bacterial infections other than spontaneous bacterial peritonitis in cirrhosis. A randomized, controlled study. J Hepatol 2012;57:759-65. doi:10.1016/j.jhep.2012.06.013

78 Leão GS, John Neto G, Jotz RF, Mattos AA, Mattos ÂZ. Albumin for cirrhotic patients with extraperitoneal infections: A meta-analysis. J Gastroenterol Hepatol 2019;34:2071-6. doi:10.1111/jgh.14791

79 Caraceni P, Riggio O, Angeli P, et al, ANSWER Study Investigators. Long-term albumin administration in decompensated cirrhosis (ANSWER): an open-label randomised trial. Lancet 2018;391:241729. doi:10.1016/S0140-6736(18)30840-7

80 Solà E, Solé C, Simón-Talero M, et al. Midodrine and albumin for prevention of complications in patients with cirrhosis awaiting liver transplantation. A randomized placebo-controlled trial. J Hepatol 2018;69:1250-9. doi:10.1016/j.jhep.2018.08.006

81 Fernández J, Navasa M, Planas R, et al. Primary prophylaxis of spontaneous bacterial peritonitis delays hepatorenal syndrome and improves survival in cirrhosis. Gastroenterology 2007;133:818-24. doi:10.1053/j.gastro.2007.06.065

82 Kamal F, Khan MA, Khan Z, et al. Rifaximin for the prevention of spontaneous bacterial peritonitis and hepatorenal syndrome in cirrhosis: a systematic review and meta-analysis. Eur J Gastroenterol Hepatol 2017;29:1109-17. doi:10.1097/ MEG.0000000000000940

83 Ruiz-del-Arbol L, Monescillo A, Jimenéz W, Garcia-Plaza A Arroyo V, Rodés J. Paracentesis-induced circulatory dysfunction: mechanism and effect on hepatic hemodynamics in cirrhosis. Gastroenterology 1997;113:579-86. doi:10.1053/gast.1997.v113. pm9247479

84 Ginès P, Titó L, Arroyo V, et al. Randomized comparative study of therapeutic paracentesis with and without intravenous albumin in cirrhosis. Gastroenterology 1988;94:1493-502. doi:10.1016/00165085(88)90691-9

85 Bernardi M, Caraceni P, Navickis RJ, Wilkes MM. Albumin infusion in patients undergoing large-volume paracentesis: a meta-analysis of randomized trials. Hepatology 2012;55:1172-81. doi:10.1002/ hep. 24786

86 Fernández J, Monteagudo J, Bargallo X, et al. A randomized unblinded pilot study comparing albumin versus hydroxyethyl starch in spontaneous bacterial peritonitis. Hepatology 2005;42:627-34. doi:10.1002/hep.20829

87 Garcia-Martinez R, Caraceni P, Bernardi M, Gines P, Arroyo V, Jalan R. Albumin: pathophysiologic basis of its role in the treatment of cirrhosis and its complications. Hepatology 2013;58:1836-46. doi:10.1002/hep.26338

88 Zhang WJ, Frei B. Albumin selectively inhibits TNF alpha-induced expression of vascular cell adhesion molecule- 1 in human aortic endothelial cells. Cardiovasc Res 2002;55:820-9. doi:10.1016/ S0008-6363(02)00492-3

89 Chen TA, Tsao YC, Chen A, et al. Effect of intravenous albumin on endotoxin removal, cytokines, and nitric oxide production in patients with cirrhosis and spontaneous bacterial peritonitis. Scand I Gastroenterol 2009;44:619-25. doi:10.1080/00365520902719273

90 China L, Maini A, Skene SS, et al. Albumin Counteracts ImmuneSuppressive Effects of Lipid Mediators in Patients With Advanced Liver Disease. Clin Gastroenterol Hepatol 2018;16:738-747.e7. doi:10.1016/j.cgh.2017.08.027
91 China L, Skene SS, Bennett K, et al. ATTIRE: Albumin To prevenT Infection in chronic liveR failurE: study protocol for an interventional randomised controlled trial. BMI Open 2018;8:e023754.

92 European Association for the Study of the Liver. Electronic address: easloffice@easloffice.eu, European Association for the Study of the Liver. EASL Clinical Practice Guidelines for the management of patients with decompensated cirrhosis. J Hepatol 2018;69:406-60. doi:10.1016/j.jhep.2018.03.024

93 Bhutta AQ, Garcia-Tsao G, Reddy KR, et al. Beta-blockers in hospitalised patients with cirrhosis and ascites: mortality and factors determining discontinuation and reinitiation. Aliment Pharmacol Ther 2018:47:78-85 doi:10.1111/apt.14366

94 Mandorfer M, Bota S, Schwabl P, et al. Nonselective $\beta$ blockers increase risk for hepatorenal syndrome and death in patients with cirrhosis and spontaneous bacterial peritonitis. Gastroenterology 2014;146:1680-90.e1. doi:10.1053/j. gastro.2014.03.005

95 Ibrahim ES, Alsebaey A, Zaghla H, Moawad Abdelmageed S, Gameel K, Abdelsameea E. Long-term rifaximin therapy as a primary prevention of hepatorenal syndrome. Eur J Gastroenterol Hepatol 2017;29:1247-50. doi:10.1097/ MEG 0000000000000967

96 Dong T, Aronsohn A, Gautham Reddy K, Te HS. Rifaximin Decreases the Incidence and Severity of Acute Kidney Injury and Hepatorenal Syndrome in Cirrhosis. Dig Dis Sci 2016;61:3621-6. doi:10.1007/ s10620-016-4313-0

97 Velez JC, Nietert PJ. Therapeutic response to vasoconstrictors in hepatorenal syndrome parallels increase in mean arterial pressure: a pooled analysis of clinical trials. Am J Kidney Dis 2011;58:928-38. doi:10.1053/j.ajkd.2011.07.017

98 Facciorusso A, Chandar AK, Murad MH, et al. Comparative efficacy of pharmacological strategies for management of type 1 hepatorenal syndrome: a systematic review and network meta-analysis. Lancet Gastroenterol Hepatol 2017;2:94-102. doi:10.1016/S24681253(16)30157-1

99 Jamil K, Pappas SC, Devarakonda KR. In vitro binding and receptormediated activity of terlipressin at vasopressin receptors $\mathrm{V}_{1}$ and $\mathrm{V}_{2}$.J Exp Pharmacol 2017:10:1-7. doi:10.2147/JEP.S146034

100 Tanoue A, Ito S, Honda K, et al. The vasopressin V1b receptor critically regulates hypothalamic-pituitary-adrenal axis activity under both stress and resting conditions. J Clin Invest 2004;113:302-9. doi:10.1172/JCl200419656

101 Wong F, Pappas SC, Boyer TD, et al, REVERSE Investigators. Terlipressin Improves Renal Function and Reverses Hepatorenal Syndrome in Patients With Systemic Inflammatory Response Syndrome. Clin Gastroenterol Hepatol 2017;15:266-272.e1. doi:10.1016/j.cgh.2016.07.016

102 Russell JA, Walley KR. Vasopressin and its immune effects in septic shock. J Innate Immun 2010;2:446-60. doi:10.1159/000318531

103 Krag A, Bendtsen F, Pedersen EB, Holstein-Rathlou NH, Møller S. Effects of terlipressin on the aquaretic system: evidence of antidiuretic effects. Am I Physiol Renal Physiol 2008:295:F1295300. doi:10.1152/ajprenal.90407.2008

104 Solà E, Lens S, Guevara M, et al. Hyponatremia in patients treated with terlipressin for severe gastrointestinal bleeding due to portal hypertension. Hepatology 2010;52:1783-90. doi:10.1002/ hep. 23893

105 Laterre PF, Berry SM, Blemings A, et al, SEPSIS-ACT Investigators. Effect of Selepressin vs Placebo on Ventilator- and VasopressorFree Days in Patients With Septic Shock: The SEPSIS-ACT Randomized Clinical Trial. JAMA 2019;322:1476-85. doi:10.1001/ jama.2019.14607

106 He X, Su F, Taccone FS, et al. A Selective V(1A) Receptor Agonist, Selepressin, Is Superior to Arginine Vasopressin and to Norepinephrine in Ovine Septic Shock. Crit Care Med 2016;44:2331. doi:10.1097/CCM.0000000000001380

107 Merkel C, Gatta A, Zuin R, Finucci GF, Nosadini R, Ruol A. Effect of somatostatin on splanchnic hemodynamics in patients with liver cirrhosis and portal hypertension. Digestion 1985;32:92-8. doi:10.1159/000199224

108 Møller S, Brinch K, Henriksen JH, Becker U. Effect of octreotide on systemic, central, and splanchnic haemodynamics in cirrhosis / Hepatol 1997;26:1026-33. doi:10.1016/S0168-8278(97)80111-0

109 Pomier-Layrargues G, Paquin SC, Hassoun Z, Lafortune M, Tran A. Octreotide in hepatorenal syndrome: a randomized, double-blind, placebo-controlled, crossover study. Hepatology 2003;38:238-43. doi:10.1053/ihep.2003.50276

110 Angeli P, Volpin R, Piovan D, et al. Acute effects of the ora administration of midodrine, an alpha-adrenergic agonist, on renal hemodynamics and renal function in cirrhotic patients with ascites. Hepatology 1998;28:937-43. doi:10.1002/hep.510280407

111 Angeli P, Volpin R, Gerunda G, et al. Reversal of type 1 hepatorenal syndrome with the administration of midodrine and octreotide. Hepatology 1999;29:1690-7. doi:10.1002/hep.510290629 
112 Wong F, Pantea L, Sniderman K. Midodrine, octreotide, albumin, and TIPS in selected patients with cirrhosis and type 1 hepatorenal syndrome. Hepatology 2004;40:55-64. doi:10.1002/hep.20262

113 Solanki P, Chawla A, Garg R, Gupta R, Jain M, Sarin SK. Beneficial effects of terlipressin in hepatorenal syndrome: a prospective, randomized placebo-controlled clinical trial. / Gastroenterol Hepatol 2003;18:152-6. doi:10.1046/j.1440-1746.2003.02934.x

114 Neri S, Pulvirenti D, Malaguarnera M, et al. Terlipressin and albumin in patients with cirrhosis and type I hepatorenal syndrome. Dig Dis Sci 2008;53:830-5. doi:10.1007/s10620-007-9919-9

115 Sanyal AJ, Boyer T, Garcia-Tsao G, et al, Terlipressin Study Group. A randomized, prospective, double-blind, placebocontrolled trial of terlipressin for type 1 hepatorenal syndrome. Gastroenterology 2008;134:1360-8. doi:10.1053/j. gastro.2008.02.014

116 Boyer TD, Sanyal AJ, Wong F, et al, REVERSE Study Investigators. Terlipressin Plus Albumin Is More Effective Than Albumin Alone in Improving Renal Function in Patients With Cirrhosis and Hepatorenal Syndrome Type 1. Gastroenterology 2016;150:1579-1589.e2. doi:10.1053/j.gastro.2016.02.026

117 Wong F, Curry M, Reddy R, et al, CONFIRM Study Investigators. LO5 The CONFIRM study: A North American randomized controlled tria (RCT) of terlipressin plus albumin for the treatment of hepatorenal syndrome type 1 (HRS-1). Hepatology 2019;70(Suppl 1):10

118 Alessandria C, Ottobrelli A, Debernardi-Venon W, et al. Noradrenalin vs terlipressin in patients with hepatorenal syndrome: a prospective, randomized, unblinded, pilot study. J Hepatol 2007;47:499-505. doi:10.1016/j.jhep.2007.04.010

119 Sharma P, Kumar A, Shrama BC, Sarin SK. An open label, pilot, randomized controlled trial of noradrenaline versus terlipressin in the treatment of type 1 hepatorenal syndrome and predictors of response. Am J Gastroenterol 2008;103:1689-97. doi:10.1111/ j.1572-0241.2008.01828x

120 Singh V, Ghosh S, Singh B, et al. Noradrenaline vs. terlipressin in the treatment of hepatorenal syndrome: a randomized study. I Hepatol 2012;56:1293-8.

121 Cavallin M, Kamath PS, Merli M, et al, Italian Association for the Study of the Liver Study Group on Hepatorenal Syndrome. Terlipressin plus albumin versus midodrine and octreotide plus albumin in the treatment of hepatorenal syndrome: A randomized trial. Hepatology 2015;62:567-74. doi:10.1002/hep.27709

122 Arora V, Maiwall R, Rajan V, et al. Terlipressin Is Superior to Noradrenaline in the Management of Acute Kidney Injury in Acute on Chronic Liver Failure. Hepatology 2020;71:600-10. doi:10.1002/ hep. 30208

123 Ortega R, Ginès P, Uriz J, et al. Terlipressin therapy with and without albumin for patients with hepatorenal syndrome: results of a prospective, nonrandomized study. Hepatology 2002;36:941-8. doi:10.1053/jhep.2002.35819

124 Cavallin M, Piano S, Romano A, et al. Terlipressin given by continuous intravenous infusion versus intravenous boluses in the treatment of hepatorenal syndrome: A randomized controlled study. Hepatology 2016;63:983-92. doi:10.1002/hep.28396

125 Duvoux C, Zanditenas D, Hézode C, et al. Effects of noradrenalin and albumin in patients with type I hepatorenal syndrome: a pilot study. Hepatology 2002;36:374-80. doi:10.1053/jhep.2002.34343

126 Rodríguez E, Elia C, Solà E, et al. Terlipressin and albumin for type-1 hepatorenal syndrome associated with sepsis. I Hepatol 2014;60:955-61. doi:10.1016/j.jhep.2013.12.032

127 Piano S, Schmidt HH, Ariza X, et al, EASL CLIF Consortium, European Foundation for the Study of Chronic Liver Failure (EF Clif). Association Between Grade of Acute on Chronic Liver Failure and Response to Terlipressin and Albumin in Patients With Hepatorenal Syndrome. Clin Gastroenterol Hepatol 2018;16:1792-1800.e3. doi:10.1016/j. cgh.2018.01.035

128 Bortoluzzi A, Ceolotto G, Gola E, et al. Positive cardiac inotropic effect of albumin infusion in rodents with cirrhosis and ascites: molecular mechanisms. Hepatology 2013;57:266-76. doi:10.1002/ hep. 26021

129 Stocker R, Glazer AN, Ames BN. Antioxidant activity of albumin-bound bilirubin. Proc Natl Acad Sci U S A 1987;84:5918-22. doi:10.1073/ pnas.84.16.5918

130 Cantin AM, Paquette B, Richter M, Larivée P. Albumin-mediated regulation of cellular glutathione and nuclear factor kappa B activation. Am J Respir Crit Care Med 2000;162:1539-46. doi:10.1164/ajrccm.162.4.9910106

131 Lejon S, Frick IM, Björck L, Wikström M, Svensson S. Crystal structure and biological implications of a bacterial albumin binding module in complex with human serum albumin. J Biol Chem 2004;279:429248. doi:10.1074/ibc.M406957200

132 Mitzner SR, Stange J, Klammt S, et al. Improvement of hepatorenal syndrome with extracorporeal albumin dialysis MARS: results of a prospective, randomized, controlled clinical trial. Liver Transpl 2000;6:277-86. doi:10.1053/lv.2000.6355
133 Wong F, Raina N, Richardson R. Molecular adsorbent recirculating system is ineffective in the management of type 1 hepatorenal syndrome in patients with cirrhosis with ascites who have failed vasoconstrictor treatment. Gut 2010;59:381-6.

134 Ginès P, Uriz J, Calahorra B, et al. Transjugular intrahepatic portosystemic shunting versus paracentesis plus albumin for refractory ascites in cirrhosis. Gastroenterology 2002;123:1839-47. doi:10.1053/gast.2002.37073

135 Azoulay D, Castaing D, Majno P et al. Salvage transjugula intrahepatic portosystemic shunt for uncontrolled variceal bleeding in patients with decompensated cirrhosis. J Hepatol 2001;35:590-7. doi:10.1016/S0168-8278(01)00185-4

136 Guevara M, Ginès P, Bandi JC, et al. Transjugular intrahepatic portosystemic shunt in hepatorenal syndrome: effects on renal function and vasoactive systems. Hepatology 1998;28:416-22 doi:10.1002/hep.510280219

137 Song T, Rössle M, He F, Liu F, Guo X, Qi X. Transjugular intrahepatic portosystemic shunt for hepatorenal syndrome: A systematic review and meta-analysis. Dig Liver Dis 2018;50:323-30. doi:10.1016/j. dld.2018.01.123

138 Zhang Z, Maddukuri G, Jaipaul N, Cai CX. Role of renal replacement therapy in patients with type 1 hepatorenal syndrome receiving combination treatment of vasoconstrictor plus albumin. / Crit Care 2015;30:969-74. doi:10.1016/j.jcrc.2015.05.006

139 Lenhart A, Hussain S, Salgia R. Chances of Renal Recovery or Liver Transplantation After Hospitalization for Alcoholic Liver Disease Requiring Dialysis. Dig Dis Sci 2018;63:2800-9. doi:10.1007/ s10620-018-5170-9

140 Fraley DS, Burr R, Bernardini J, Angus D, Kramer DJ, Johnson JP. Impac of acute renal failure on mortality in end-stage liver disease with or without transplantation. Kidney Int 1998;54:518-24. doi:10.1046/ j.1523-1755.1998.00004.x

141 Wong LP, Blackley MP, Andreoni KA, Chin H, Falk RJ, Klemmer PJ. Survival of liver transplant candidates with acute renal failure receiving renal replacement therapy. Kidney Int 2005;68:362-70. doi:10.1111/j.1523-1755.2005.00408.x

142 Allegretti AS, Parada XV, Eneanya ND, et al. Prognosis of Patients with Cirrhosis and AKI Who Initiate RRT. Clin J Am Soc Nephrol 2018;13:16-25. doi:10.2215/CJN.03610417

143 European Association for the Study of the Liver. EASL clinical practice guidelines on the management of ascites, spontaneous bacterial peritonitis, and hepatorenal syndrome in cirrhosis. J Hepatol 2010:53:397-417. doi:10.1016/j.jhep.2010.05.004

144 Iwatsuki S, Popovtzer MM, Corman JL, et al. Recovery from "hepatorenal syndrome" after orthotopic liver transplantation. N Eng Med 1973:289:1155-9. doi:10.1056/NEJM197311292892201

145 Runyon BAAASLD Practice Guidelines Committee. Management of adult patients with ascites due to cirrhosis: an update. Hepatology 2009;49:2087-107. doi:10.1002/hep.22853

146 Israni AK, Xiong H, Liu J, et al. Predicting end-stage renal disease after liver transplant. Am J Transplant 2013;13:1782-92. doi:10.1111/ ajt. 12257

147 Organ Procurement and Transplantation Network. Policies. 2020. https://optn.transplant.hrsa.gov/media/1200/optn_policies.pdf.

148 Chauhan K, Azzi Y, Faddoul G, et al. Pre-liver transplant renal dysfunction and association with post-transplant end-stage renal disease: A single-center examination of updated UNOS recommendations. Clin Transplant 2018;32:e13428. doi:10.1111/ ctr.13428

149 Nadim MK, Genyk YS, Tokin C, et al. Impact of the etiology of acute kidney injury on outcomes following liver transplantation acute tubular necrosis versus hepatorenal syndrome. Liver Transp/ 2012;18:539-48. doi:10.1002/lt.23384

150 OPTN/UNOS Kidney Transplantation Committee. Simultaneous Liver Kidney (SLK) Allocation Policy. https://optn.transplant.hrsa.gov/ media/1192/0815-12 SLK Allocation.pdf.

151 Runyon BA. Management of adult patients with ascites due to cirrhosis: update 2012. https://www.aasld.org/sites/default/ files/2019-06/141020 Guideline Ascites 4UFb 2015.pdf.

152 Conrad KP. Unveiling the vasodilatory actions and mechanisms of relaxin. Hypertension 2010;56:2-9. doi:10.1161/ HYPERTENSIONAHA.109.133926

153 Fallowfield IA, Hayden AL, Snowdon VK, et al. Relaxin modulates human and rat hepatic myofibroblast function and ameliorates portal hypertension in vivo. Hepatology 2014;59:1492-504. doi:10.1002/ hep. 26627

154 Snowdon VK, Lachlan NJ, Hoy AM, et al. Serelaxin as a potential treatment for renal dysfunction in cirrhosis: Preclinical evaluation and results of a randomized phase 2 trial. PLOS Med 2017:14:e1002248 doi:10.1371/journal.pmed 1002248

155 Stine JG, Wang J, Cornella SL, et al. Treatment of Type-1 Hepatorenal Syndrome with Pentoxifylline: A Randomized Placebo Controlled Clinical Trial. Ann Hepatol 2018;17:300-6. doi:10.5604/01.3001.0010.8661 